\title{
Carbon Footprint of tourism in Barcelona
}

\author{
Anna Rico ${ }^{\mathrm{a}}$, Julia Martínez-Blanco ${ }^{\mathrm{a}, \mathrm{b}}$, Marc Montlleóc $^{\mathrm{c}}$, Gustavo Rodríguez $^{\mathrm{c}}$, Nuno Tavares $^{\mathrm{c}}$, \\ Albert Arias $^{\mathrm{d}}$, Jordi Oliver-Solà ${ }^{\mathrm{a}, \mathrm{b}, *}$ \\ ${ }^{a}$ Institut de Ciència i Tecnologia Ambientals (ICTA), Universitat Autònoma de Barcelona (UAB), Campus UAB, 08193 \\ Bellaterra, Barcelona, Catalonia (Spain). \\ ${ }^{\mathrm{b}}$ Inèdit, Inèdit Innovació, S.L. UAB Research Park, Eureka Building, 08193 Bellaterra, Barcelona, Catalonia (Spain). \\ ${ }^{c}$ Barcelona Regional - Urban Development Agency. Carrer 60, 25-27. Edifici Z. 2a planta. Sector A. Zona Franca, 08040 \\ Barcelona, Catalonia (Spain). \\ ${ }^{\mathrm{d}}$ Barcelona City Council. Carrer Llacuna 162, 08018 Barcelona, Catalonia (Spain).
}

* Corresponding author: jordi@ineditinnova.com

\begin{abstract}
This study evaluates the carbon footprint (CF) of Barcelona tourist activity taking into account the above 30 million visitors who visit the city every year. This study analyzes the main sources of emissions considering direct (Scope 1) and indirect emissions (Scope 2 and 3) as a consequence of energy use. This research has been carried out in close collaboration with Barcelona City Council and in the context of the new Strategic Tourism Plan for Barcelona city. The impacts of arrival and departure transport, accommodation, leisure and professional activities and Intra-urban transport from Barcelona city were all included. The total CF of Barcelona tourist activity is about $9.6 \mathrm{MtCO}_{2} \mathrm{eq} / \mathrm{year}$, which represents an emission of $96.9 \mathrm{~kg} \mathrm{CO} 2 \mathrm{eq} /$ visitor day. The main source of emissions is arrival and departure transport (95.6\%), and particularly aviation. These results show that if substantial reductions in $\mathrm{CO}_{2}$ emissions are to be achieved, initiatives strategically focused on transport and also accommodation are necessary.
\end{abstract}

Key Words: carbon dioxide emissions, energy, sustainable tourism, air transport, greenhouse gas, city level.

\section{Introduction}

In the 2003 Djerba Declaration, the World Tourism Organization (WTO) recognized the bi-directional relationship between tourism and climate change. On the one hand, climate change has an impact on tourist destinations and tourist flows. On the other hand, tourism is a major contributor to climate change mainly due to the use of fossil fuels that leads to the emission of greenhouse gases (GHG). Currently, the tourism industry accounts for more than 9\% of global GDP (UNWTO, 2015).

\subsection{The importance of tourism on global greenhouse gas emissions}

Tourism is a collection of social and economic activities with high energy and carbon intensity and in expansion, for those reasons its effect on climate change is expected to grow considerably in the future. That is why international organizations such as the UN World Tourism Organization (UNWTO), the 
United Nations Environment Program (UNEP) and the Organization for Economic Co-operation and Development (OECD) are already studying the impact of tourism on climate change.

According to a recent study (Lenzen et al., 2018), between 2009 and 2013, tourism's global carbon footprint has increased from 3.9 to $4.5 \mathrm{Gt} \mathrm{CO}_{2} \mathrm{eq}$, four times more than previously estimated, accounting for about $8 \%$ of global greenhouse gas emissions. That emissions may be higher, up to $14 \%$, if we include radiative forcing, i.e. the warming caused by $\mathrm{CO}_{2}$ and other greenhouse gases emitted by planes in the stratosphere (WTO, WMO, \& UNEP, 2008).

To understand the magnitude of these numbers it should be noted that if we compare national carbon emissions with tourism emissions, tourism would be the 5th largest polluter worldwide. In addition, by 2035, emissions from tourism in absolute terms are expected to be more than double that of 2005. Most of this growth is associated with increased air traffic (WTO, WMO, \& UNEP, 2008). In this context, the distance to the destination and the choice of transport for getting there and back are the most important decisions.

\subsection{Main contributing touristic activities}

Long distance trips by plane amount globally for less than $3 \%$ of all trips but they cause $70 \%$ of the harmful emissions connected to tourism (Grimm, et. al., 2008). According to UNWTO, an average holiday trip (considering that in average a tourist trip, which includes international and a big share of domestic touristic trips, lasts 4.15 days) causes 0.25 tons of $\mathrm{CO}_{2}$ eq per person.

The contribution of tourism to GHG emissions is particularly significant for those destinations where tourists overwhelmingly arrive by air (Dwyer, Forsyth, Spurr, \& Hoque, 2010). Gössling (2013) reports that in the Caribbean islands, the share of emissions related to air travel was between $44 \%$ and $70 \%$ of total emissions across the region. On Haiku City in China, for example, it was found that transportation $\mathrm{CO}_{2}$ emissions of airplane travel was $88 \%$ of total city tourism transportation and it represented $24 \%$ of the city's total emissions (Pu \& Mi, 2016). Another study about the energy flows of tourism in Menorca Island shows that air travel contributes the most (77\%) to total emissions (Sanyé-Mengual et al., 2014).

Filimonau, Dickinson and Robbins (2014) conducted a study about the carbon impact of short-haul tourism and they support the idea that transportation generates the largest carbon footprint, showing that the most significant carbon savings can be achieved by switching from air and car-based travel to train and coach journeys. Peeters and Schouten (2006) worked on the ecological footprint of inbound tourism and transport to Amsterdam, and they conclude that the main part of the environmental pressure of inbound tourism originates from transport (70\%) and accommodation (21\%). (Stefan Gössling, 2013)(Filimonau, Dickinson, \& Robbins, 2014)

Although transport is recognized as the highest contributor, many other tourism related activities contribute significantly to tourism GHG emissions because of their high energy intensity, and particularly accommodation and leisure activities. When considering tourist accommodation there are factors that take place on the same premises such as heating, air-conditioning and the maintenance of bars, restaurants, pools, laundry and so on that must be taking in to account (Michailidou, Vlachokostas, Moussiopoulos, \& Maleka, 2015).

Usually accommodations of higher category present more services that are closely linked to a larger environmental impact (Accor hotels, 2016). A comparative study realized in a Canary Islands shown that 
the higher star-rated hotels have consumption levels and emissions triple those of lower star-rated ones, and five times that of the lowest (Díaz Pérez, et al., 2018). The electricity consumption makes a significant contribution to the environmental profile of five-star hotel categories, and represents more than $50 \%$ of their total greenhouse gas emissions (Puig, et al., 2017). Becken, Frampton and Simmons (2001), underline the importance of accommodation as a source of carbon dioxide emissions. On the other hand, Becken and Simmons (2002) also investigate the consumption patterns of tourist attractions and activities in New Zealand. Their study explains the importance of leisure activities in energy use and concludes that visits to tourist attractions, such as museums, generally consume less energy than tourist motorized activities.

\subsection{The relevant paper of cities on global tourism trends}

Cities concentrate the majority of the world's economic activities; more than $50 \%$ of its residents are localized in urban areas thus cities have a vital role to play in the recognition of a Green Economy (Zorpas, Voukkali \& Navarro, 2017). Although a number of studies have been done on the carbon footprint (CF) of tourism in different regions, mostly in countries and islands (Björnsson, 2014; Grimm et al., 2008; Sisman \& Associates, 2007), this study is a pioneer because it is one of the first to be carried out calculating the carbon footprint of tourism in a city.

Moreover, city trips are the fastest-growing market segment and have soared by 58\% since 2013 to reach a $20 \%$ of the holiday market share, with a strong $15 \%$ rise in European cities (IPK International \& ITB Academy, 2017). The rise of low cost airlines has also brought increased interest in cities and attracting a new type of product: city breaks (UNWTO, 2012). European Cities Marketing (ECM) announced a 3.6\% growth in city tourism in 2016 , with the domestic market increasing by $6.0 \%$ and the international market by $2.3 \%$.

In general terms, high concentration of tourists causes considerable environmental deterioration, increased energy and water consumption, as well as waste generation. To supply the tourist areas it is necessary to create additional infrastructure and services in a limited area and with limited resources (Kreag, 2001). Most tourism-related activities require direct energy use in the form of fossil fuels (such as petroleum, coal or gas), or indirectly, in the form of electricity often generated from precisely these same fossil fuels.

To minimize the emissions effect, cities have a possible path of development in building a tourist offer based on sustainable, environmentally friendly and responsible tourism (Maćkiewicz \& KoneckaSzydłowska, 2017). Urban green tourism (eco-tourism) is also a response to that need, as it was emphasized by the participants of the 3rd Global Summit on City Tourism (held in Barcelona in December 2014 and promoted by UNWTO), to make a city enjoyable to all, i.e. residents, tourists and investors, and to spread the benefits of urban tourism to its surroundings, thus reinforcing its impact and managing congestion.

\subsection{The case study of Barcelona: a big touristic spot}

Barcelona tourism is highly influenced by the increasing trend of urban tourism. During the period 20082015, Barcelona has experienced an increase of $25 \%$ in the number of tourists visiting the city (Barcelona City Council, 2015). The last few years have seen a proliferation of low cost airline companies in Barcelona airport: $70 \%$ of passengers that flew to Barcelona-El Prat Airport in 2016 did it with low-cost 
airlines (Aena, 2017). Barcelona is a clear example of the European trend toward short city touristic trips, where many tourists use low-cost airline companies and platforms to rent cheaper accommodation from particulars. The average length of a stay in Barcelona's tourism accommodation (i.e. hotels, apartments, etc.) is 2.9 overnights (Barcelona City Council, 2016a), and Barcelona City Council estimated that $45 \%$ of tourists chose Houses for Tourist Use (HTU) (Duatis, Buhigas, \& Cruz, 2016). Moreover, Barcelona tourism, similar to other Mediterranean areas, is also influenced by seasonality due to the good climate conditions and the proximity to the coast (Barcelona City Council, 2015; Sanyé-Mengual et al., 2014).

With a population of more than 1.6 million inhabitants, (3.3 million if the whole Barcelona metropolitan area is considered) Barcelona is today one of the world's leading tourist destinations. Barcelona city is a major cultural and economic center in South-Western Europe and a growing business center (UNWTO, 2012). It is also a strategic transport hub. As one of the most important ports in Europe it received 749 annual cruises carrying 2.5 million passengers in 2014 (Port of Barcelona \& Barcelona Tourism, 2015b). Barcelona's international airport handles around 40 million passengers per year and the city has an extensive motorway network (Barcelona Tourism et al., 2016). The city has also become the new highspeed rail link between Spain and France, currently the second longest continuous high-speed rail line in the world.

All this contributes to making the tourism sector one of the most important economic generators of the city. It represents around 13\% of Barcelona GDP (Garriga \& Rigall, 2015) and is also connected with other key sectors such as transport, hospitality, retail, etc. According to the Global destination Cities Index 2016 (Hedrick-Wong \& Choog, 2016), Barcelona is ranked as the 12th most visited city in the world in 2016 and 4th on the European continent (with 8.2 million international tourists that stay overnight in hotels), only behind London (19.88M), Paris (18.03M) and Istanbul (11.95M)

Local authorities estimated that the total number of visitors - summing tourists that stay overnight and day-trippers - to Barcelona city throughout the year 2015 was approximately 33 million and that mainly concentrate in some very specific areas of the city (Barcelona Tourism et al., 2016). Due to this high volume of tourism, the City Council has device a Strategic Plan to address and manage the impact that tourism has on the city. In the latest version of Barcelona Strategic Tourism Plan, there is the intention to include the environmental vector taking to account the $\mathrm{CF}$ as a decision-making factor. This study was prepared within this context.

The main objective of this paper is to quantify the carbon footprint of tourism in Barcelona as a tool to identify the main sources of GHG emissions and propose mitigation strategies. The study is focused on the $\mathrm{CF}$ analysis of the main tourist activities (arrival and departure transport, accommodation, leisure and professional activities and interurban transport). Through this analysis we will define which mode of transport, accommodation type or tourist activity has most impact on the CF of the city. Furthermore, the study makes a distinction between tourists and day-trippers, to measure the $\mathrm{CO}_{2}$ emissions generated by the two different profiles. The results obtained from Barcelona are also benchmarked with other similar studies in cities or regions. 


\section{Materials and Methods}

\subsection{Carbon footprint Methodology}

The framework methodology used in this study is defined by ISO 14040:2006 for the Life Cycle Assessment (LCA) of products, processes and systems. This methodology has been adapted to the tourist phenomena in the city of Barcelona and also takes into account some recommendations from other standards for the calculation of the carbon footprint of cities (GHG Protocol and PAS 2070) and of organizations (ISO 14064-1:2006).

The most extensive definition of the CF was done by Wiedmann and Minx (2008), who suggest that CF is "a measure of the exclusive total amount of $\mathrm{CO}_{2}$ emissions that is directly and indirectly caused by an activity or is accumulated over the life stages of a product". This calculation framework includes the entire life cycle, i.e. from the obtaining of the raw materials needed for the activity or system, including the production phases, to the management of the generated waste. CF calculation serves as an assessment tool in terms of GHG emissions and then, it serves to manage and reduce these emissions. After calculating the $\mathrm{CF}$, its detailing helps to identify weaknesses - areas of high emissions that can be eliminated or improved. Thus, carbon footprint is an indicator of sustainable development (Andreea, Marian, \& Dimitriu, 2013).

All the greenhouse gases accounted by the Intergovernmental Panel on Climate Change (IPCC) in a 100year perspective were taken into account in the study, using the characterization factors for each gas recommended in the IPCC reports (2013). (Hartmann, Tank, \& Rusticucci, 2013)

Although some studies point out that the emission of GHG to the upper layers of the atmosphere has a pronounced effect on climate change, this study does not consider that radiative forcing effect due to the uncertainty on the specific multiplier effect. According to several sources, values range from 1 to 4.7 (Lee et al., 2009; Grassl, H. \& Brockhagen, D., 2007).

\subsection{Object and scope of the study}

The object of study are the activities related to tourism carried out by approximately 33 million visitors (Barcelona City Council, 2016b) that Barcelona received in 2015. These visitors are categorized according to the characteristics of their trip as tourists, day-trippers or cruise passengers (Figure 1). This is the first study where these visitors' profiles are analyzed separately, calculating the environmental impact for each one of them.

In this study a visitor is defined as any person not resident in the Barcelona Metropolitan Region (BMR) travelling into the municipality of Barcelona and staying for less than 28 days, and who is over 15 years old. Tourists are visitors who stay overnight, one night or more, in tourist accommodations or private houses in the city of Barcelona. In a survey of tourists the average duration of a tourist trip was calculated as 5 days (Barcelona Tourism et al., 2016), for this reason in this study we will consider that a tourist trip lasts an average of 5 days. 


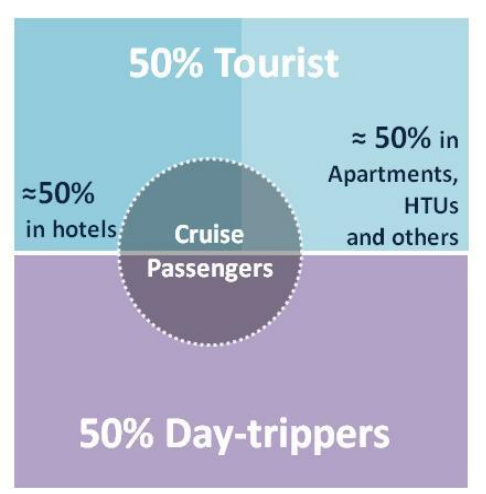

Figure 1. Distribution of Barcelona visitors
On the other hand, day-trippers are visitors who spend the day visiting the city but without overnight stays in the city. Day-trippers are difficult to be accounted because there is not any systematic method to record them. For this reason Barcelona City Council, and according to previous estimations of the institution, uses the hypothesis that the number of day-trippers is the same as the number of tourists. Three types of day-trippers are included in the analysis: Catalonia residents living outside the Barcelona Metropolitan Region and visiting Barcelona (henceforth, Catalan day-trippers); cruise passengers in transit who visit the city as one of the stops on the cruise (cruise day-

trippers); and tourists accommodated in other destinations around the city that visit Barcelona for one day (tourist day-trippers). There is a final category to be considered. This is cruise visitors, i.e. those who arrive or depart from the Port of Barcelona on a cruise. They are included in this study as two main groups: those who visit the city for a few hours (included as cruise day-trippers) and those who spend at least one night (accounted as tourists). With 2.5 million cruise passengers in 2014 Barcelona has become the leading cruise port in Europe and the Mediterranean and the fourth cruise port worldwide (Port of Barcelona \& Barcelona Tourism, 2015b). Barcelona stands out for its role as turnaround port (where all the operations for the start and end of the cruise take place).

The study includes the whole life cycle for four tourism activity categories: Arrival and departure transport, accommodation, leisure and professional activities, and intra-urban transport. As some of these activities involve services or infrastructures belonging to the city that are also used by local citizens, the study only accounts for the corresponding part of the impact allocated to tourism. The study focuses on energy flows that are a very relevant environmental aspect of the tourist sector, according to previous studies (Gössling, 2013). Therefore, GHG emissions from all the stages of the energy production cycle and for every source of energy (mainly fossil fuels and electricity) are included for each tourist activity analyzed. It should be noted that energy use of capital goods is not included due to lack of data. The CF of tourism takes into account three scopes: Scope 1, 2 and 3. Scope 1 includes direct emissions inside the borders of the city. Scope 2 accounts the indirect emissions associated with the consumption of electricity. Finally, Scope 3 considers others upstream and downstream indirect emissions (Table 1). This study considers the total amount of GHG emissions directly or indirectly emitted. Direct emissions are emitted during the tourist activity and inside the municipality of Barcelona. Indirect emissions-are mainly produced outside the limits of the municipality area, but are a consequence of the tourist activity in Barcelona. The study does not include the direct fugitive emissions associated with HVAC systems because the data are not available. 


\begin{tabular}{|c|c|c|c|}
\hline & Scope 1 & Scope 2 & Scope 3 \\
\hline $\begin{array}{l}\text { Arrival } \\
\& \\
\text { Departure Transport }\end{array}$ & & & $\begin{array}{l}\text { Indirect emissions related with } \\
\text { the production and combustion } \\
\text { of fuel for the means of transport } \\
\text { for tourists and day-trippers. The } \\
\text { emissions related with the } \\
\text { infrastructures are not included. }\end{array}$ \\
\hline Accommodation & \multirow{3}{*}{$\begin{array}{l}\text { Direct emissions from } \\
\text { the combustion of fuels } \\
\text { in stationary and mobile } \\
\text { sources inside the } \\
\text { borders of the city. }\end{array}$} & \multirow{3}{*}{$\begin{array}{l}\text { Indirect emissions related } \\
\text { to the generation of } \\
\text { electricity and heat, cool } \\
\text { or steam (thanks to district } \\
\text { heating and cooling } \\
\text { systems) that is consumed } \\
\text { in the city. }\end{array}$} & \multirow{3}{*}{$\begin{array}{l}\text { Indirect emissions associated } \\
\text { with the production of the fuels } \\
\text { used in stationary and mobile } \\
\text { sources of the city. }\end{array}$} \\
\hline $\begin{array}{l}\text { Leisure and } \\
\text { professional activities }\end{array}$ & & & \\
\hline $\begin{array}{l}\text { Intra-urban } \\
\text { Transport }\end{array}$ & & & \\
\hline
\end{tabular}

Table 1. Study system boundaries. Scope definition.

The compilation of data from the tourist sector is a challenge because it is not considered as a specific sector in the national accounts and also there are multiple interconnections with other sectors. However, in this case the main data sources for the study are statistical data provided by Barcelona City authorities. A very important one is the Survey on Tourist Activity in the City of Barcelona 2015 (Barcelona City Council, 2016a) that is carried out annually on 6,000 Barcelona tourists. In order to establish a characterization of the three typologies of day-trippers, information of 3 distinct surveys was used. Data of Catalan day-trippers was collected mainly using the Survey of Daily Mobility in Catalonia 2006 (IERMB, 2007a; IERMB, 2007b) data of tourist day-trippers was collected from the Annual Survey of Characterization of tourists in Barcelona Province 2015 (Barcelona Provincial Council, 2016) and cruise day-trippers data was collected using the Cruise Passengers Survey 2014 Barcelona (Port of Barcelona and Barcelona City Council, 2015a). In order to improve the quality of the data available in the tourism accommodation sector, Barcelona Tourism, within the framework of the Strategic Tourism Plan, launched in 2016 a survey of tourist accommodation in the city (Tourist Directorate, 2017). Data were collected from 53 tourist apartments; 6 Five-Star or Grand-Luxury hotels; 31 Four-Star or Four-Star Superior hotels; 13 Three-Star hotels; 7 Two-Star hotels; 7 One-Star hotels; and 21 other accommodations distributed between guesthouses and hostels. It is estimated that the accommodation survey has an error of less than $20 \%$. For leisure and professional activities, data was collected from our own survey carried out on 30 tourist attractions with more of 100,000 visitors/year, the six most-used transport services focused specially for tourists and the two main centers of events and congresses.

All the data used in this study is sourced from official reports and surveys which have been carried out for and by public organizations and institutions. Therefore, the analysis is based on the best quality of information available. For the modeling of the GHG emissions associated to the provision of the tourist services (such as transports, accomodation, attractions, etc.) through the combustion and production of each fuel and electricity consumed, specialized databases were used: Ecoinvent v3.2 and DEFRA 2015. In Table 2 the considerations and the data sources for each activity category are summarized. 


\begin{tabular}{|c|c|c|c|c|c|}
\hline Categories & Sub-Categories & \multicolumn{2}{|c|}{ Type of visitor } & Considerations & Sources \\
\hline \multirow{4}{*}{$\begin{array}{l}\text { Arrival \& } \\
\text { Departure } \\
\text { Transport }\end{array}$} & \multirow{4}{*}{$\begin{array}{l}\text { Airplane /Bus/ } \\
\text { Train/ Rental Car/ } \\
\text { Own Car/ Cruise/ } \\
\text { Others }\end{array}$} & \multicolumn{2}{|l|}{ Tourist } & $\begin{array}{l}\text { It includes the GHG emissions derived from the transport of arrival and } \\
\text { departure of the tourists from their country of residence to the city of } \\
\text { Barcelona. In the case that the tourist arrives by airplane, the transport } \\
\text { from the airport to the city center is also included. }\end{array}$ & (Barcelona City Council, 2016a) \\
\hline & & \multirow{3}{*}{$\begin{array}{l}\text { Day- } \\
\text { trippers }\end{array}$} & $\begin{array}{l}\text { Catalan day- } \\
\text { trippers }\end{array}$ & $\begin{array}{l}\text { Arrival and departure in their own car, train or coach from their } \\
\text { residence to the city of Barcelona. }\end{array}$ & $\begin{array}{l}\text { (IERMB, 2007b) } \\
\text { (Barcelona Provincial Council, 2016) }\end{array}$ \\
\hline & & & $\begin{array}{l}\text { Cruise } \\
\text { passengers in } \\
\text { transit }\end{array}$ & $\begin{array}{l}\text { Part of the cruise journey is counted and also a part of their arrival by } \\
\text { plane to Europe. The approximation of GHG have been realized taking } \\
\text { into account that a cruise trip lasts on average } 10,5 \text { days and only one } \\
\text { day have been used to visit Barcelona. The previous stopover to the } \\
\text { Port of Barcelona is also counted if it was in Spain, Italy, France or } \\
\text { Mediterranean Islands. An average distance of } 964 \mathrm{~km} \text { is considered } \\
\text { (weighted average according to the passenger traffic and nautical } \\
\text { distances). }\end{array}$ & $\begin{array}{l}\text { (Port of Barcelona and Barcelona City } \\
\text { Council,2015a) } \\
\text { (Port of Barcelona and Barcelona City } \\
\text { Council,2015b) }\end{array}$ \\
\hline & & & $\begin{array}{l}\text { Tourists from } \\
\text { other } \\
\text { destinations }\end{array}$ & $\begin{array}{l}\text { For day-trippers who are staying in municipalities near Barcelona, } \\
\text { besides transport from their accommodation to the city, part of the } \\
\text { journey from their country of origin to Catalonia is considered. The } \\
\text { approximation of GHG has been realized taking into account that a } \\
\text { tourist trip lasts on average } 5 \text { days and only one day has been used to } \\
\text { visit Barcelona. }\end{array}$ & (Barcelona Provincial Council, 2016) \\
\hline Accommodation & $\begin{array}{l}\text { Hotels / Hostels/ } \\
\text { Tourist } \\
\text { Apartments/ HTUs }\end{array}$ & \multicolumn{2}{|c|}{$\begin{array}{l}\text { All visitors } \\
\text { (Tourist \&Day-trippers) }\end{array}$} & $\begin{array}{l}\text { Accommodations are basically occupied by tourists. Therefore the } \\
\text { analysis includes } 100 \% \text { of the GHG emissions related with energy use at } \\
\text { these establishments. } \\
\text { Due to lack of data the consumption of products and amenities have not } \\
\text { been included. }\end{array}$ & $\begin{array}{l}\text { (Barcelona City Council \& Barcelona Energy } \\
\text { Agency, 2013) } \\
\text { (Barcelona Tourism et al., 2016) } \\
\text { (Barcelona City Council, 2016d) } \\
\text { (Tourism Directorate, 2017) } \\
\end{array}$ \\
\hline $\begin{array}{l}\text { Leisure \& } \\
\text { professional } \\
\text { activities }\end{array}$ & $\begin{array}{l}\text { Tourist attractions/ } \\
\text { Special tourist } \\
\text { transports/ Events } \\
\text { \& Congresses }\end{array}$ & \multicolumn{2}{|c|}{$\begin{array}{c}\text { All visitors } \\
\text { (Tourist \&Day-trippers) }\end{array}$} & $\begin{array}{l}\text { The proportional part of energy use that corresponds to tourism has been } \\
\text { calculated for the emissions associated with the use of energy in } 29 \\
\text { tourist attractions, special tourist transports of the city and also data } \\
\text { about the main events \& conferences centers have also been included. }\end{array}$ & $\begin{array}{l}\text { Own Survey used for the } 30 \text { Tourist } \\
\text { attractions, the six special tourist transport } \\
\text { more used and the two main centers of events } \\
\text { and congresses. }\end{array}$ \\
\hline $\begin{array}{l}\text { Intra-urban } \\
\text { Transport }\end{array}$ & $\begin{array}{l}\text { Metro / Taxi / } \\
\text { Train / Bus / Own } \\
\text { Vehicle/ Others }\end{array}$ & \multicolumn{2}{|c|}{$\begin{array}{c}\text { All visitors } \\
\text { (Tourist \&Day-trippers) }\end{array}$} & $\begin{array}{l}\text { The study includes the share of GHG emissions related to fuel and } \\
\text { electricity consumption from the city's public transport, taxi, private and } \\
\text { rental cars, coaches, etc. }\end{array}$ & $\begin{array}{l}\text { (Barcelona City Council, 2017) } \\
\text { (Barcelona City Council, 2016a) } \\
\text { (Barcelona City Council \& Barcelona Energy } \\
\text { Agency, 2013) } \\
\text { (Barcelona City Council, 2016b). } \\
\text { (Barcelona City Council, 2016c) }\end{array}$ \\
\hline
\end{tabular}

Table 2: System considerations and data sources 
There are other categories relevant to calculate the impact of tourism in the city, such as shops, catering and waste. These are activities or services shared by citizens and tourists. The energy use of these categories were not included in the study for lack of data quality which makes it difficult to discern which proportion pertains exclusively to tourist activity. They are relevant but their dependence on the tourist sector is not clear. Even so these categories have been evaluated in an approximate way, calculating the energy use generated for Barcelona tourists in these sectors. The information used is from the Distribution of tourist spending according to the survey of 2015 (Barcelona City Council, 2016a) and the Energy balance of Barcelona 2013 (Barcelona City Council \& Barcelona Energy Agency, 2013).

\section{Inventory}

According to the considerations and system boundaries presented, most relevant data are detailed in the following sub-sections for each category.

\subsection{Arrival and departure transport}

\subsubsection{Tourists}

There are 16,466,039 Barcelona tourists and around the $75 \%$ of them are from the EU and the remaining $25 \%$ are long-haul tourists. Their main arrival and departure transport mode is by plane (78\%), followed far behind by train and by their own car (Table 3).

\begin{tabular}{lcc}
\hline \multicolumn{3}{c}{ Distribution per origin } \\
\hline Origin & $\mathbf{N}^{\mathbf{0}}$ tourists & $\begin{array}{c}\text { \% of } \\
\text { tourists }\end{array}$ \\
\hline Catalonia & 186,110 & $1 \%$ \\
\hline Spain & $2,458,953$ & $15 \%$ \\
\hline France & $1,616,793$ & $10 \%$ \\
\hline $\begin{array}{l}\text { Rest of } \\
\text { Europe } \\
<1500 \mathrm{~km}\end{array}$ & $5,671,129$ & $34 \%$ \\
\hline $\begin{array}{l}\text { Rest of } \\
\text { Europe } \\
>1500 \mathrm{~km}\end{array}$ & $2,517,147$ & $15 \%$ \\
\hline Africa & 299,203 & $2 \%$ \\
\hline $\begin{array}{l}\text { North } \\
\text { America }\end{array}$ & $1,468,564$ & $9 \%$ \\
\hline $\begin{array}{l}\text { South } \\
\text { America }\end{array}$ & $1,229,751$ & $7 \%$ \\
\hline Asia & 705,460 & $4 \%$ \\
\hline Oceania & 312,928 & $2 \%$ \\
\hline Total & $\mathbf{1 6 , 4 6 6 , 0 3 9}$ & $\mathbf{1 0 0 \%}$ \\
\hline & & \\
\hline
\end{tabular}

\begin{tabular}{|c|c|c|c|c|c|c|c|c|}
\hline \multicolumn{9}{|c|}{ Modality of transport (\%) } \\
\hline Plane & Train & $\begin{array}{r}\text { Private } \\
\text { Car }\end{array}$ & $\begin{array}{r}\text { Rental } \\
\text { Car }\end{array}$ & $\begin{array}{r}\text { Private } \\
\text { Bus }\end{array}$ & $\begin{array}{r}\text { Interurban } \\
\text { bus }\end{array}$ & $\begin{array}{r}\text { Ferry } \\
\text { Ship }\end{array}$ & Cruise & Others \\
\hline $1 \%$ & $46 \%$ & $32 \%$ & $1 \%$ & $4 \%$ & $15 \%$ & $0 \%$ & $0 \%$ & $0 \%$ \\
\hline $33 \%$ & $38 \%$ & $16 \%$ & $0 \%$ & $5 \%$ & $7 \%$ & $0 \%$ & $0 \%$ & $0 \%$ \\
\hline $58 \%$ & $12 \%$ & $20 \%$ & $0 \%$ & $3 \%$ & $6 \%$ & $0 \%$ & $0 \%$ & $0 \%$ \\
\hline $92 \%(*)$ & $2 \%$ & $2 \%$ & $0 \%$ & $1 \%$ & $1 \%$ & $0 \%$ & $0 \%$ & $0 \%$ \\
\hline $92 \%{ }^{(*)}$ & $3 \%$ & $1 \%$ & $1 \%$ & $0 \%$ & $1 \%$ & $0 \%$ & $0 \%$ & $0 \%$ \\
\hline $91 \%{ }^{(*)}$ & $2 \%$ & $0 \%$ & $0 \%$ & $3 \%$ & $5 \%$ & $0 \%$ & $0 \%$ & $0 \%$ \\
\hline $81 \%{ }^{(*)}$ & $9 \%$ & $0 \%$ & $1 \%$ & $1 \%$ & $3 \%$ & $2 \%$ & $2 \%$ & $0 \%$ \\
\hline $88 \% \%^{(*)}$ & $7 \%$ & $0 \%$ & $2 \%$ & $1 \%$ & $1 \%$ & $0 \%$ & $0 \%$ & $0 \%$ \\
\hline $91 \%{ }^{(*)}$ & $6 \%$ & $0 \%$ & $0 \%$ & $0 \%$ & $1 \%$ & $0 \%$ & $0 \%$ & $0 \%$ \\
\hline $78 \%{ }^{(*)}$ & $11 \%$ & $2 \%$ & $3 \%$ & $0 \%$ & $2 \%$ & $1 \%$ & $4 \%$ & $0 \%$ \\
\hline $78,5 \%$ & $10,0 \%$ & $5,6 \%$ & $0,6 \%$ & $1,5 \%$ & $2,8 \%$ & $0,4 \%$ & $0,5 \%$ & $0,2 \%$ \\
\hline
\end{tabular}

(*) For calculations is assumed that the $100 \%$ of the tourists take the plane to arrive to Europe and the others percentages of transport modes are from transport used from intermediates destinations to Barcelona city.

Table 3. Origin and arrival \& departure transport mode of Barcelona tourists, 2015. 
As the surveys only ask for the origin and the type of transport used to get to Barcelona, the same information is assumed as valid to calculate the departures. The distance from any country to Barcelona is calculated as follows: for aviation, the airport with most transit from the country of origin; for train or road transport, from the capital. For the tourists who arrive by plane, the profile of the main means of transport used to connect the airport to the city center is: Taxi (35.3\%), Public Transport (33.9\%) and Private car (24.2\%).

Another information gap is related to those tourists that claim to visit more than one destination during their trip (apart from Barcelona). There is no data available on how many other destinations will they visit, nor the length of the total trip. In these cases, it is considered that the trip has at least two destinations: Barcelona and a second city or place, and the length of the stay is considered the same in both destinations.

\subsubsection{Day-trippers}

On the other hand, day-trippers distributed in "Catalan day-trippers" (46.0\%), "cruise day-trippers" (7.2\%) and "tourists day-trippers" (46.8\%). The allocation of part of the trip has been made taking into account the total average duration of the trip, depending on its origin, and also considering that the day-trippers are only in Barcelona for one day. In the following table (Table 4) the number of day-trippers for each category and their transport distribution is shown:

\begin{tabular}{|c|c|c|c|c|c|}
\hline \multirow[b]{2}{*}{ Day-trippers category } & \multirow{2}{*}{$\begin{array}{l}N^{o} \text { of tourist } \\
\text { day-trippers }\end{array}$} & \multicolumn{4}{|c|}{ Main transport from residence to accomotadion } \\
\hline & & Airplane & Own vehicle & Train & Private Bus \\
\hline Tourist day-trippers & $7,691,434.89$ & $46.6 \%$ & $42.8 \%$ & $5.3 \%$ & $5.3 \%$ \\
\hline Spain & $2,690,787.87$ & $16.7 \%$ & $68.2 \%$ & $7.6 \%$ & $7.6 \%$ \\
\hline Europe & $4,173,183.40$ & $55.2 \%$ & $34.9 \%$ & $5.0 \%$ & $5.0 \%$ \\
\hline Rest of the world & $827,463.62$ & $100.0 \%$ & $0.0 \%$ & $0.0 \%$ & $0.0 \%$ \\
\hline Catalan Day-trippers & $7,576,146$ & - & $85 \%$ & $4 \%$ & $11 \%$ \\
\hline Cruise day-trippers & $1,202,301$ & $16 \%(*)$ & - & - & - \\
\hline TOTAL & $16,469,881$ & - & - & - & - \\
\hline
\end{tabular}

(*) \% of cruise day-trippers who come to visit Barcelona by transoceanic flight

Table 4. Number of trippers per category and mode of transport.

\subsection{Accommodation}

The city has more than 10,000 establishments that offer more than 120,000 accommodation places to visitors (Table 5). The study only takes into account energy consumption of the accommodation analyzed in the survey of Barcelona accommodation (Tourist Directorate, 2017). Based on the results of the survey, the average value of electricity and gas consumption per year is estimated for each type of accommodation, using the number of overnight stays and unit energy consumption. Energy use per room day varies considerably depending on the type of accommodation. 


\begin{tabular}{|c|c|c|c|c|c|c|}
\hline Typology & Category & $\begin{array}{r}\text { Overnight } \\
\text { stays }\end{array}$ & $\begin{array}{r}\text { Natural gas } \\
(\mathbf{k W h} / \\
\text { overnight } \\
\text { stay }) \\
\end{array}$ & $\begin{array}{r}\text { Electricity } \\
(\mathbf{k W h} / \\
\text { overnight stay })\end{array}$ & $\begin{array}{r}\text { Total Energy Use } \\
(\mathbf{k W h} / \\
\text { Overnight stay) }\end{array}$ & $\begin{array}{l}\text { Total Energy Use } \\
\text { (kWh/room·day ) }\end{array}$ \\
\hline \multirow[t]{6}{*}{ Hotels } & & $17,589,235$ & 12.7 & 16.56 & 29.26 & 39.5 \\
\hline & $*$ & 697,927 & 5.5 & 6.2 & 11.7 & 17.6 \\
\hline & $* *$ & $1,105,197$ & 6.7 & 5.6 & 12.3 & 17.5 \\
\hline & $* * *$ & $4,267,815$ & 8.5 & 12.9 & 21.3 & 28.3 \\
\hline & $* * * *$ & $9,305,566$ & 17.4 & 21.2 & 38.6 & 48.1 \\
\hline & $* * * * *$ & $2,212,731$ & 25.4 & 36.9 & 62.4 & 86.2 \\
\hline Guesthouse & & $1,299,617$ & 3.3 & 4.9 & 8.2 & 21.1 \\
\hline $\begin{array}{l}\text { Tourist } \\
\text { apartments }\end{array}$ & & 696,318 & 2.3 & 8.4 & 10.7 & 12.8 \\
\hline Hostels & & $2,150,825$ & 3.3 & 4.9 & 8.2 & 21.1 \\
\hline $\begin{array}{l}\text { HTU's - } \\
\text { registered }\end{array}$ & & $9,472,357$ & & & 10.7 & \\
\hline $\begin{array}{l}\text { HTU's- not } \\
\text { registered }\end{array}$ & & $8,263,413$ & 2.3 & 8.4 & & 12.8 \\
\hline $\begin{array}{l}\text { Total } \\
\text { Barcelona }\end{array}$ & & $39,471,766$ & 4.9 & 8.6 & 13.41 & 21.5 \\
\hline
\end{tabular}

Table 5. Accommodation capacity and energy use for different accommodation types, 2016. (Tourism Directorate, 2017).

As shown in table 5, hotels are those with the highest energy use per unit, compared to the other accommodation options. Four and Five-Star hotels host $65 \%$ of hotels overnight stays and on average use three times more energy than lower category hotels.

HTU or vacation rental are included in the analysis because this is one of the most widely-used hosting options in Barcelona (45\% of overnight stays). HTU is the legal figure by the Catalan Catalonia Tourism Law $(13 / 2002)$ for entire flats or houses ceded to third parties, repeatedly, for less than 31 days and in return for economic compensation. Data for the HTU's not registered (i.e. without governmental license) are estimated thanks to a study of the City council not published that uses a spider searcher at the main webs for HTU's searching and rental (Duatis, Buhigas, \& Cruz, 2016). One last type of accommodation, family's or friends' houses, have not been considered in the study because their consumption could be similar to resident energy consumption and it is already accounted as domestic energy consumption in the city records (Duatis, Buhigas, \& Cruz, 2016).

\subsection{Leisure and professional activities}

The study includes the energy use of the 30 most-visited tourist attractions in 2015, which received more than 100,000 visitors. It also includes the 6 transport services focused specially for tourists in the city, such as the cable car or tourist buses and boats. In 2015 these 30 tourist attractions achieved a total of 17.8 million visits and 4.2 million annual trips in special tourist transports. The data used was collected from our own survey where we asked specifically about consumption of electricity, fuel and water, fugitive emissions from airconditioning, waste generation, as well as the percentage of tourists among visitors during 2015, which turned to be around $65 \%$. 
Finally, with regard to professional activity, data from the main events and conference centers have also been incorporated. According to Barcelona City Council (2016a), in 2015, 656,000 tourists attended business events in Barcelona, and there were 2,268 business events in the city. Other professional activities (such as meetings with clients, visits to facilities, administrative tasks, etc.) have not been included due to lack of data.

\subsection{Intra-urban transport}

The majority of visitors travel around the city by public collective transport $(83.43 \%)$, being the metro the mostused intra-urban transport (Table 6). Nevertheless, train is the mode of interurban transport with the highest unit consumption, followed by rental and private cars and taxi. Based on the data collected by Barcelona City Council and the different operators of this Intraurban transport, the total number of journeys made inside the municipal area for each mode of transport, and the energy use derived from these has been estimated.

\begin{tabular}{|c|c|c|c|}
\hline $\begin{array}{l}\text { Intra-urban } \\
\text { transport }\end{array}$ & $\begin{array}{l}\text { Distribution of } \\
\text { Visitors Journeys }\end{array}$ & Resource & $\begin{array}{r}\text { Unit } \\
\text { Consumption } \\
(\mathrm{kWh} / \text { trip } \cdot \text { person })\end{array}$ \\
\hline Metro & $65.33 \%$ & Electricity & 0.45 \\
\hline RENFE- Train & $3.35 \%$ & Electricity & 3.18 \\
\hline FGC -Train & $1.43 \%$ & Electricity & 0.78 \\
\hline Tram & $1.31 \%$ & Electricity & 0.23 \\
\hline \multirow[b]{2}{*}{ Bus } & \multirow{2}{*}{$12.01 \%$} & Diesel & 0.58 \\
\hline & & $\begin{array}{r}\text { Natural } \\
\text { Gas } \\
\end{array}$ & 0.59 \\
\hline \multirow{4}{*}{ Taxi } & \multirow{4}{*}{$9.96 \%$} & Diesel & 2.26 \\
\hline & & Petrol & 0.22 \\
\hline & & $\begin{array}{r}\text { Natural } \\
\text { Gas } \\
\end{array}$ & 0.01 \\
\hline & & GLP & 0.13 \\
\hline Private Bus & $0.81 \%$ & Diesel & 1.17 \\
\hline \multirow{2}{*}{ Private cars } & \multirow{2}{*}{$5.35 \%$} & Diesel & \multirow{2}{*}{2.63} \\
\hline & & Petrol & \\
\hline \multirow{2}{*}{$\begin{array}{l}\text { Rental } \\
\text { cars }\end{array}$} & \multirow{2}{*}{$0.41 \%$} & Diesel & \multirow{2}{*}{2.63} \\
\hline & & Petrol & \\
\hline Total & $188,372,101$ & & - \\
\hline
\end{tabular}

\section{Results and discussion}

Table 6. Use of urban transport modes by Barcelona visitors, 2015.

\subsection{Total carbon footprint}

The results show that the annual GHG emissions associated with tourism in Barcelona is 9,578,359 tonnes $\mathrm{CO}_{2}$ eq, which represents an emission of $96.93 \mathrm{~kg} \mathrm{CO}_{2} \mathrm{eq} /$ visitor$\bullet$ day. The average $\mathrm{CF}$ of a tourist is 111.64 $\mathrm{kg} \mathrm{CO}$ eq / day and $43.04 \mathrm{~kg} \mathrm{CO}_{2}$ eq / day for a day-tripper. The differences observed between the $\mathrm{CF}$ of tourists and day-trippers may be due to several reasons:

- Tourists staying overnight in the city, thus adding accommodation impacts to their footprint.

- Day-trippers spend only one day in the city, which means that only a small part of their arrival and departure transport from the area can be allocated to Barcelona.

- A significant number of day-trippers are Catalan, i.e. from nearby areas, and have a much lower carbon footprint related to transport. 


\begin{tabular}{|c|c|c|c|c|c|c|c|}
\hline & Category & $\begin{array}{r}\text { Total CF } \\
\text { (tonnes } \\
\mathrm{CO}_{2} \text { eq } \\
\text { /year) }\end{array}$ & $\begin{array}{r}\text { Relative } \\
\text { Impact }(\%)\end{array}$ & $\begin{array}{r}\text { Average } \\
\text { visitor } \cdot \text { day } \\
\left(\mathrm{kg} \mathrm{CO} \mathrm{CO}_{2}\right. \\
\mathrm{eq})\end{array}$ & $\begin{array}{r}\text { Scope 1 } \\
\text { (tonnes } \mathrm{CO}_{2} \\
\mathrm{eq})\end{array}$ & $\begin{array}{r}\text { Scope 2 } \\
\text { (tonnes } \mathrm{CO}_{2} \\
\text { eq) }\end{array}$ & $\begin{array}{r}\text { Scope } 3 \\
\text { (tonnes } \mathrm{CO}_{2} \\
\text { eq) }\end{array}$ \\
\hline & $\begin{array}{l}\text { Arrival \& departure } \\
\text { transport }\end{array}$ & $9,184,457$ & $95.9 \%$ & 92.9 & $0.0 \%$ & $0.0 \%$ & $100.0 \%$ \\
\hline \multirow{3}{*}{ 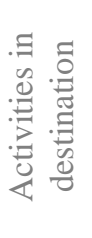 } & Accommodation & 297,891 & $3.1 \%$ & 3.0 & $19.8 \%$ & $77,5 \%$ & $2.7 \%$ \\
\hline & $\begin{array}{l}\text { Leisure and } \\
\text { professional } \\
\text { activities }\end{array}$ & 32,148 & $0.3 \%$ & 0.3 & $23.5 \%$ & $72.3 \%$ & $4.2 \%$ \\
\hline & Intra-urban transport & 63,862 & $0.7 \%$ & 0.6 & $38.0 \%$ & $54.5 \%$ & $7.4 \%$ \\
\hline & TOTAL & $9,578,359$ & $100.0 \%$ & 96.93 & $\begin{array}{l}90,776 \\
(0.9 \%)\end{array}$ & $\begin{array}{r}289,079 \\
(3.0 \%)\end{array}$ & $\begin{array}{r}9,198,503 \\
(96.0 \%)\end{array}$ \\
\hline
\end{tabular}

Table 7. Distribution of the Carbon footprint of Barcelona Tourism

A $96.03 \%$ of the impact is linked to the life cycle and combustion of the fuel used for the arrival and departure transport (Scope 3). Direct emissions resulted from the combustion of stationary sources and mobile sources (scope 1) and indirect emissions derived from Energy use (Scope 2), represent only a $0.95 \%$ and $3.02 \%$ of the total emissions, respectively (Table 7).

Analyzing the results per category, $95.9 \%$ of emissions generated are from arrival and departure transport. The activities at destination represent a $4.1 \%$ of total emissions and $3.99 \mathrm{~kg} \mathrm{CO}_{2}$ eq / visitor-day. The highest contribution to the emissions inside the city comes from accommodation (3.1\%), followed by intra-urban transport $(0.7 \%)$ and leisure and professional activities $(0.3 \%)$. The emissions derived from consumption of imported electricity (Scope 2) are responsible for $73 \%$ of the total impact at destination. The report "Climate Change and Tourism. Responding to Global Challenges" (WTO, WMO, \& UNEP, 2008) quantifies the average emissions per tourist at a global level as $60.24 \mathrm{~kg} \mathrm{CO}_{2} /$ person-day, showing the distribution of emissions by categories: arrival and departure transport is responsible for $75 \%$ of the total emissions followed by accommodation (21\%) and Activities (4\%). Although the global average of $\mathrm{kg} \mathrm{CO}_{2} /$ person॰day is $37 \%$ lower than the result obtained for Barcelona, the magnitude is similar. The methodological differences in the realization of the study may be the cause of the variations between the results obtained, for example while the WTO considers only the $\mathrm{CO}_{2}$ emissions, the study for the city of Barcelona includes all GHG gases. In addition, we must take into account the high international component of tourism in the city, where $78 \%$ of the arrival and departure journeys are by airplane (Table 3), while considering the world average, only $17 \%$ of the trips are made by airplane. In this line, the average distance considered in a single journey to arrive to Barcelona $(4,857 \mathrm{~km}$ for air travel and $832 \mathrm{~km}$ non-air travel) is higher than the distance considered in the UNWTO study $(3,801 \mathrm{~km}$ for air travel and $600 \mathrm{~km}$ non-air travel). In addition, the result for Barcelona is emphasized by the international character of the city and also because Barcelona is a destination for short duration trips. Other studies have shown that the majority of the environmental footprint can be accounted by travel to and from the destination, with figures ranging from 59\% to 97\% (Dolnicar, Laesser, \& Matus, 2010; Peeters \& Schouten, 2006). 


\subsection{Carbon footprint per categories}

\subsubsection{Arrival and departure transport}

As seen in Table 8, the main source of emissions are the transport of arrival and departure, but there are large differences between tourists (average of $103.1 \mathrm{~kg} \mathrm{CO}_{2}$ eq/visitor-day) and day-trippers (average of $42.1 \mathrm{~kg}$ $\mathrm{CO}_{2}$ eq/visitor $\bullet$ day). With $8,461,728.40$ tonnes $\mathrm{CO}_{2}$ eq/year the transportation of tourists from their origin to Barcelona represents up to $92 \%$ of the total transport emissions for all Barcelona visitors, being aviation the main source of GHG emissions (89,3\% of GHG emissions associated with arrival and departure transport of visitors) (Table 8 ). In this case all the emissions generated are from the scope 3.

\begin{tabular}{|c|c|c|c|c|}
\hline Visitors & Types & $\begin{array}{l}\text { Total CF (tones } \\
\mathrm{CO}_{2} \text { eq /year) }\end{array}$ & $\begin{array}{r}\mathrm{kg} \mathrm{CO}_{2} \mathrm{eq} / \\
\text { visitor }\end{array}$ & $\begin{array}{c}\mathrm{kg} \mathrm{CO} \mathrm{CO}_{2} \mathrm{eq} \\
\text { visitor·day }\end{array}$ \\
\hline \multirow{10}{*}{ Tourist } & Trip from origin & $8,461,728.40$ & 513,7 & 102,75 \\
\hline & Airplane & $97 \%$ & 605.7 & 121.15 \\
\hline & Train-High-speed rail & $1 \%$ & 52.9 & 10.57 \\
\hline & Own Vehicle & $1 \%$ & 127.2 & 25.43 \\
\hline & Others & $1 \%$ & 198.8 & 39.7 \\
\hline & $\overline{\text { City-airport journey }}$ & $29,907.78$ & 2.8 & 0.6 \\
\hline & Taxi & $54 \%$ & 2.7 & 0.5 \\
\hline & Public Bus & $39 \%$ & 3.3 & 0.7 \\
\hline & Others private transports & $8 \%$ & 2.8 & 0.6 \\
\hline & TOTAL & $8,491,636.19$ & 515.6 & 103.1 \\
\hline \multirow{11}{*}{$\begin{array}{l}\text { Day- } \\
\text { trippers }\end{array}$} & Catalonia Day-trippers & $225,891.11$ & 29.8 & 29.8 \\
\hline & Own Vehicle & $96 \%$ & 33.6 & 33.6 \\
\hline & Train & $1 \%$ & 6.2 & 6.2 \\
\hline & Private Bus & $3 \%$ & 9.1 & 9.1 \\
\hline & Cruise Day-trippers & $79,454.29$ & 66.1 & 66.1 \\
\hline & Cruises & $67 \%$ & 44.1 & 44.1 \\
\hline & Transoceanic flights & $33 \%$ & 135.4 & 135.4 \\
\hline & Tourists Day-trippers & $387,475.68$ & 50.4 & 50.4 \\
\hline & $\begin{array}{l}\text { From origin to neighboring } \\
\text { municipality }\end{array}$ & $85 \%$ & 42.6 & 42.6 \\
\hline & $\begin{array}{l}\text { From neighboring } \\
\text { municipality to Barcelona }\end{array}$ & $15 \%$ & 7.7 & 7.7 \\
\hline & TOTAL & $692,821.08$ & 42.1 & 42.1 \\
\hline \multicolumn{2}{|c|}{ Total arrival/departure transport } & $9,184,457.27$ & 278.8 & 92.9 \\
\hline
\end{tabular}

Table 8. Distribution of Departure and Arrival Transport Carbon footprint.

Regarding the origin of tourists, European tourists (75\% of total tourists according to Table 3) are responsible for $42 \%$ of transport emissions (Table 9). Despite representing only $25 \%$ of total tourists, transoceanic tourists (from America, Asia, Oceania and Africa) are responsible for $58.02 \%$ of GHG emissions from transport because of their long-haul aviation needs. Indeed, depending on the origin of tourists, the average emissions 
for arrival and departure transport can range from $19 \mathrm{~kg}$ of $\mathrm{CO}_{2}$ eq for a tourist from Catalonia, or $159 \mathrm{~kg}$ of $\mathrm{CO}_{2}$ eq for a tourist from France, to $2162 \mathrm{~kg} \mathrm{CO}_{2}$ eq for for a tourist from Oceania (Table 9).

\begin{tabular}{|c|c|c|c|c|}
\hline Origin & $\begin{array}{c}\% \text { of } \\
\text { tourists }\end{array}$ & Total CF (tones $\mathrm{CO}_{2}$ eq /year) & Relative Impact (\%) & $\mathrm{kg} \mathrm{CO} 2 \mathrm{eq} /$ tourist \\
\hline Catalonia & $1 \%$ & 3505 & $0.0 \%$ & 19 \\
\hline Spain & $15 \%$ & 278,550 & $3.3 \%$ & 113 \\
\hline France & $10 \%$ & 257,867 & $3.0 \%$ & 159 \\
\hline $\begin{array}{l}\text { Rest of Europe } \\
<1500 \mathrm{~km}\end{array}$ & $34 \%$ & $1,702,271$ & $20.1 \%$ & 300 \\
\hline $\begin{array}{l}\text { Rest of Europe } \\
>1500 \mathrm{~km}\end{array}$ & $15 \%$ & $1,310,150$ & $15.5 \%$ & 520 \\
\hline Africa & $2 \%$ & 140,983 & $1.7 \%$ & 471 \\
\hline North America & $9 \%$ & $1,424,164$ & $16.8 \%$ & 970 \\
\hline South America & $7 \%$ & $1,469,733$ & $17.4 \%$ & 1195 \\
\hline Asia & $4 \%$ & $1,198,064$ & $14.2 \%$ & 1698 \\
\hline Oceania & $2 \%$ & 676,439 & $8.0 \%$ & 2162 \\
\hline Total & $100 \%$ & $8,461,728$ & $100.0 \%$ & 514 \\
\hline
\end{tabular}

Table 9. Distribution of Arrival and Departure transport CF according to tourist origin

The international character of tourism in Barcelona should be noted because domestic tourism only accounts for $3.3 \%$ of total tourist and about the $3 \%$ of the emissions associated. Analyzing the arrival and departure transport mode used for tourists, from France and Spain, the transport modes other than air transport have a significant weight in the results (Table 3). For both countries, train and own car are transport modes that are commonly used (Spain 55\%; France 32\%), but in the GHG emissions, they get a lower relative weighting (Spain 36\%; France 20\%) in comparison to air transport (average of 66\%).

Regarding the day-trippers, although they are about 16 million their relative contribution to GHG emissions is much lower. Transport used by "Tourist day-trippers" represents $4.2 \%$ of the total arrival and departure transport, mainly due to transport from origin to the neighboring municipality where they stay overnight. On the other hand, "Catalonia day-trippers" contribute to a $2.5 \%$, mainly due to the use of their own vehicle as a mode of transport. Finally, "Cruise day-trippers" contribute only to $0.9 \%$ of arrival and departure transport GHG emissions because they are less in number (Table 8). However, they have the largest unitary emissions among the types within the day-trippers category (66.1 $\mathrm{kg} \mathrm{CO}_{2}$ eq / cruise day-tripper-day).

\subsubsection{Accommodation}

Accommodation, with $297,891,485$ tonnes $\mathrm{CO}_{2}$ eq /year, is the activity with highest GHG emissions only taking to account the activities at destination (75.6\%). For accommodation $77.5 \%$ of emissions correspond to the scope 2, (i.e. electricity consumption) and $19.8 \%$ are direct emissions due to the combustion of natural gas in stationary sources, mainly heating boilers (scope 1).

Hotels are responsible for $70 \%$ of GHG emissions from accommodation in Barcelona, followed by HTUs with $25.2 \%$ (Table 10). Both kinds of accommodation are those that had most overnight stays during 2015 (Table 
4) and with a very similar percentage, around $45 \%$ each. Among hotels, four and five-star hotels are the ones that have more GHG emissions per overnight stay, representing $85.7 \%$ of the emissions attributed to the hotel sector in Barcelona. In contrast, hostels and guesthouses are the accommodation options with less GHG emissions per overnight stay, probably because these kinds of accommodations are usually smaller, offer less services and guests often share some areas and services, thus being more economic options.

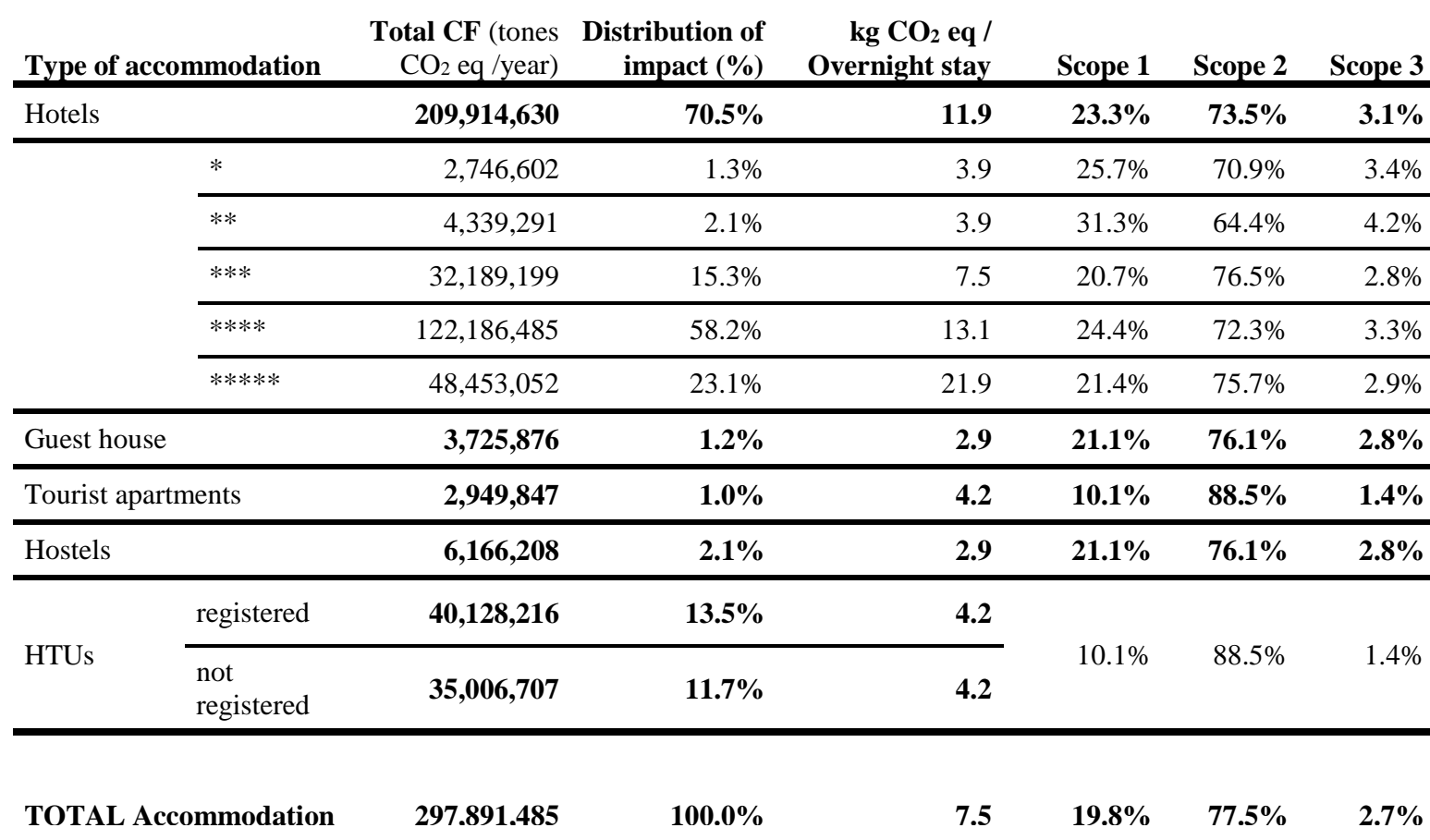

Table 10. Distribution of accommodation carbon footprint

According to WTO, WMO, \& UNEP (2008) report, global average emissions per overnight stay are $15.6 \mathrm{~kg}$ $\mathrm{CO}_{2}$, considering hotels, apartments, rural lodges and campings. It is observed that the Barcelona average GHG emissions are $7.5 \mathrm{~kg} \mathrm{CO}_{2}$ bed night, therefore the result in Barcelona are half of the global average. This result is significantly lower partly because HTUs accommodation effect decreases the average. Considering that the HTUs is a fairly recent and local way of accommodation, Barcelona's average was recalculated including only the rest of accommodation types: the new value is $11.39 \mathrm{~kg} \mathrm{CO}_{2} \mathrm{eq} /$ overnight stay, closer to the world average. The result obtained is similar to the average of $19 \mathrm{~kg} \mathrm{CO} 2 \mathrm{eq} /$ overnight stay of Spanish coastland hotel study (Puig, et al., 2017). On the other hand, a report by Accor hotel chain (Accor hotels, 2016) for the year 2010 shows that overnight stay energy use was $98.3 \mathrm{kWh}$ in Sofitel five-star hotels, 71.1 kWh in Pullman five-star hotels, $51.7 \mathrm{kWh}$ in Novotel three or four-star hotels, $23.6 \mathrm{kWh}$ in Ibis two or threestar hotels and $13.4 \mathrm{kWh}$ in Formula 1 one-star hotels. The same report details that the average energy use of the Accor hotels is $600 \mathrm{kWh} / \mathrm{m} 2 \cdot$ year (primary energy) while the average consumption in residential buildings in France is $280 \mathrm{kWh} / \mathrm{m} 2$ - year. Compared to the data presented in this study (Table 5), five-star or luxury hotels in Barcelona consumed about $86.2 \mathrm{kWh} /$ room•day in 2016, a value between the $\mathrm{kWh}$ of Sofitel and Pullman Five-Star hotels. Comparing the data for one, two, three and four-star, it can be seen that the consumption of hotels in Barcelona is quite similar to that reported by Accor. A study by Gösling (2002) about Global environmental consequences of tourism, assumes an average hotel energy use of $36.11 \mathrm{kWh}$ per 
bed night. Hotels evaluated in Majorca and Cyprus (Simmons \& Lewis, 2001), other Mediterranean destinations like Barcelona, showed an average energy use per overnight stays in hotels of $14 \mathrm{kWh}$ in Majorca and $24 \mathrm{kWh}$ in Cyprus. This data confirms that Barcelona has a similar range of results than accommodation consumption for other studies, even when compared with global averages the result is a little lower, maybe accentuated by the mild weather conditions of Barcelona all year round.

\subsubsection{Leisure and Professional activities}

Leisure and professional activities is the category with less impact $(0.3 \%)$ in the total Barcelona CF. $72.3 \%$ of GHG emissions are associated to the scope 2 mainly because tourist attractions and events and congresses have intensive use of electricity.

\begin{tabular}{|c|c|c|c|c|c|c|c|c|}
\hline Sub-Category & $\begin{array}{r}N^{0} \text { of tourist } \\
\text { visits }\end{array}$ & $\begin{array}{r}\text { Energy use } \\
\text { (kWh/visit) }\end{array}$ & $\begin{array}{l}\text { kg } \mathrm{CO}_{2} \\
\text { eq/visit }\end{array}$ & $\begin{array}{r}\text { Total } \\
\mathbf{C F} \\
\text { (tones } \\
\mathrm{CO}_{2} \text { eq } \\
\text { /year) }\end{array}$ & $\begin{array}{r}\text { Distribution } \\
\text { of impact } \\
(\%)\end{array}$ & Scope 1 & Scope 2 & Scope 3 \\
\hline Tourist Attractions & $16,639,610$ & 4.2 & 1.7 & 22,109 & $68.8 \%$ & $9.10 \%$ & $89.6 \%$ & $1.2 \%$ \\
\hline $\begin{array}{l}\text { Museums and } \\
\text { Collections } \\
\end{array}$ & $5,294,296$ & 6.3 & 2.0 & 10,649 & $55.9 \%$ & $91.4 \%$ & $43.1 \%$ & $90.9 \%$ \\
\hline $\begin{array}{l}\text { Exhibition } \\
\text { Centers }\end{array}$ & 628,954 & 3.8 & 1.7 & 1081 & $8.4 \%$ & $7.0 \%$ & $4.6 \%$ & $7.0 \%$ \\
\hline $\begin{array}{l}\text { Sites of } \\
\text { Architectural } \\
\text { Interest } \\
\end{array}$ & $10,266,250$ & 1.5 & 1.0 & 10,085 & $33.4 \%$ & $1.0 \%$ & $50.8 \%$ & $1.2 \%$ \\
\hline $\begin{array}{l}\text { Recreational } \\
\text { Areas }\end{array}$ & 450,109 & 1.8 & 0.6 & 295 & $2.3 \%$ & $0.6 \%$ & $1.4 \%$ & $0.9 \%$ \\
\hline Total & $21,462,021$ & 5.53 & 1.5 & 32,148 & $100.0 \%$ & $23.5 \%$ & $72.3 \%$ & $4.2 \%$ \\
\hline
\end{tabular}

Table 11. Distribution of Carbon Footprint of leisure and professional activities and energy use per visit.

Within leisure and professional activities, tourist attractions are responsible for $68.8 \%$ of GHG emissions, followed by special tourist transports with $19.3 \%$ and the rest is attributed to events and congresses halls (Table 11). Even though, in absolute value tourist attractions have the highest impact, the unitary impact per visit is higher in special tourist transport $(1.4 \mathrm{~kg} \mathrm{CO} 2 \mathrm{eq} / \mathrm{trip})$ and in events and congresses $\left(5.9 \mathrm{~kg} \mathrm{CO}_{2}\right.$ eq/participant). That is because the large number of visitors to tourist attractions significantly reduces its unitary impact (1.7 $\mathrm{kg} \mathrm{CO}$ eq / visit). For events and congresses, it should be noted that in conferences, congresses or trade fairs delegates are counted only once, regardless of the number of days attending an event or congress. This fact can explain the high value per visit for events and congresses subcategory.

Within tourist attractions, the ones that have the greatest contribution on the CF are museums and collections $(55.9 \%)$, also presenting the highest impact per visit (Table 11). Although some tourist attractions (e.g. Sites of architectural interest) have a higher global $\mathrm{CO}_{2}$ emissions because of the higher number of visits, they end up generating less GHG emissions per unitary visit than others (e.g. museums and collections). Finally, recreational areas obtain the lowest unitary impact value of all because there are mainly outdoor spaces with less energy requirements. 
Regarding the scope distribution (Table 11), in tourist attractions and tourist events and congresses, electricity consumption (Scope 2) represents a share of GHG emissions between 83 and $90 \%$. While in the case of special tourist transports, direct emissions (scope 1) from the combustion of diesel are the source of $80 \%$ of GHG emissions. In energy terms, although museums and collections almost double the energy use per visit in comparison than exhibition centers, the results in terms of GHG are quite similar. Something similar happens in the energy comparison between tourist attractions and special tourist transport, because special tourist transport have a lower energy requirements per visit than tourist attractions, but the emission factor of diesel notably increase the unitary impact in the GHG emissions. This is mainly due to the fact that some museums and collections have contracted renewable energy and also because they use different sources of energy with different environmental performance in the CF calculations. A study about energy use patterns of tourist attractions and activities in New Zealand (Becken, Frampton \& Simmons, 2001) calculate the energy use for museums and experiences centers such as sporting complexes $(2.7 \mathrm{kWh} / \mathrm{visit})$ and large museums and parks (8.05 kWh /visit). On the other hand, Farreny et al. (2012) carried out a study about the metabolism of Catalonia cultural services analyzing the energy and water flows in museums, showing higher energy use values for museums (15.7 $\mathrm{kWh} /$ visit in average). Nevertheless, the majority of museums fall within a range of energy consumption under $10 \mathrm{kWh} /$ visit (Farreny et al., 2012) and their energy consumption is associated with emissions that contribute to global warming valued at $2.34 \mathrm{~kg}$ of $\mathrm{CO}_{2}$ per visit.

The results obtained in Barcelona have similar magnitudes than the ones showed in previous studies, with an average of $4.2 \mathrm{kWh} /$ visit in tourist attractions and $6.3 \mathrm{kWh} / \mathrm{visit}$ in the sub-category of museums and collections. The little differences between the values can be caused by the number of tourists received and for the specific energy demand of each tourist attraction.

\subsubsection{Intra-urban Transport}

Intra-urban transport of visitors in Barcelona emits 63,862 $\mathrm{CO}_{2}$ eq in a year. In relation to the emission scopes, $54.5 \%$ of emissions are from scope 2 because they are related to electricity consumption of the metro and train. $38 \%$ are direct emissions (scope 1) associated to the combustion of mostly diesel fuel, gas and others (table 12).

\begin{tabular}{lrrrrrr}
$\begin{array}{l}\text { Inter- Urban } \\
\text { transport }\end{array}$ & $\mathbf{N}^{\mathbf{0}}$ of visitors trips & $\begin{array}{r}\text { CFTotal } \\
\text { tonnes } \mathrm{CO}_{2} \text { eq) }\end{array}$ & $\begin{array}{r}\text { kg CO eq / } \\
\text { journey·person }\end{array}$ & Scope 1 & Scope 2 & Scope 3 \\
\hline Metro & $123,081,404$ & 24,610 & 0.20 & $0.0 \%$ & $100.0 \%$ & $0.0 \%$ \\
\hline RENFE-Train & $6,318,925$ & 9029 & 1.43 & $0.0 \%$ & $100.0 \%$ & $0.0 \%$ \\
\hline FGC-Train & $2,702,438$ & 944 & 0.35 & $0.0 \%$ & $100.0 \%$ & $0.0 \%$ \\
\hline Tram & $2,473,397$ & 251 & 0.10 & $0.0 \%$ & $100.0 \%$ & $0.0 \%$ \\
\hline Bus & $22,634,329$ & 6116 & 0.29 & $85.2 \%$ & $0.0 \%$ & $14.8 \%$ \\
\hline Taxi & $18,779,070$ & 14,223 & 0.76 & $83.4 \%$ & $0.0 \%$ & $16.6 \%$ \\
\hline Rental Vehicle & $10,086,132$ & 589 & 0.76 & $83.1 \%$ & $0.0 \%$ & $16.9 \%$ \\
\hline Private Vehicle & 772,643 & 7580 & 0.75 & $82.9 \%$ & $0.0 \%$ & $17.1 \%$ \\
\hline Private Bus & $1,523,762$ & 520 & 0.34 & $83.1 \%$ & $0.0 \%$ & $16.9 \%$ \\
\hline Total & & $\mathbf{6 3 , 8 6 2}$ & $\mathbf{0 . 3 4}$ & $\mathbf{3 8 . 0 \%}$ & $\mathbf{5 4 . 5 \%}$ & $\mathbf{7 . 4 \%}$ \\
\hline
\end{tabular}


The Metro is the transport system with the largest proportion emissions (38,53\%) because it is the most used mode of transport in the city (Table 6) but if the emissions per journey and person are taken into account, then metro is the second lowest $\left(0.20 \mathrm{~kg} \mathrm{CO}_{2} \mathrm{eq} /\right.$ person per trip). Taxi, rental vehicles and private vehicles have a higher contribution per journey and per person than the average of collective transports, because in each journey the emissions are divided by fewer people. On the other hand,

Table 12. Distribution of carbon footprint in urban transport

RENFE-train has the highest carbon footprint per person because it has high energy requirement, and also because it is a less popular option than metro in intra-urban displacements.

\subsubsection{Carbon footprint estimation for other sectors: shopping, restaurant services and waste}

During the study, three areas of activity related to tourism were identified: shopping, restaurant services and waste. The lack of quality data for these activities made it impossible to include them in the study. However, their potential contribution to Barcelona GHG emissions from tourism has been estimated. GHG emissions for shops and restaurants have been estimated through the calculation of: energy consumption related with both sectors by the Energy balance of Barcelona 2013 (Barcelona City Council \& Barcelona Energy Agency, 2013); and calculating which part is attributed to tourist activity taking to account the distribution of tourist and resident expenditure specified in the Barcelona survey 2015 (Barcelona City Council, 2016a). For waste, it has been assumed that tourists and residents generate the same amount and composition of waste. Table 13 shows that shops could have a CF similar to accommodation, but major changes are not observed when these categories are added to the study because arrival and departure transport emissions remain the largest with a wide difference. Nevertheless, an in-depth study would be necessary, collecting and using quality data with the aim of obtaining more reliable results.

\begin{tabular}{lrrr} 
Activity & Total CF (tonnes $\mathrm{CO}_{2}$ eq) & Relative Impact $(\%)$ & kg $\mathbf{C O}_{2}$ eq/visitor·day \\
\hline $\begin{array}{l}\text { Arrival and departure } \\
\text { transport }\end{array}$ & $9,184,457$ & $93.1 \%$ & 92.9 \\
\hline Accommodation & 297,891 & $3.0 \%$ & 3.0 \\
\hline $\begin{array}{l}\text { Leisure activities, events \& } \\
\text { congresses }\end{array}$ & 32,148 & $0.3 \%$ & 0.2 \\
\hline Intra-urban transports & 63,862 & $0.6 \%$ & 1.5 \\
\hline Shops & 226,588 & $2.3 \%$ & 1.0 \\
\hline Restaurant services & 4,841 & $0.1 \%$ & 0.0 \\
\hline Waste & 58,879 & $0.6 \%$ & 0.6 \\
\hline TOTAL & $\mathbf{9 , 8 6 8 , 6 6 6}$ & $\mathbf{1 0 0 . 0 \%}$ & $\mathbf{9 9 . 2}$ \\
\hline
\end{tabular}

Table 13. Impact of each category in absolute and relative value for Total CF, including shops, restaurants and waste.

\subsubsection{Comparative with other studies}

In the academic field, there are some CF studies of tourism at national and regional or island level, but previous antecedents have not been found at the city level. This fact complicates the comparability of the results obtained but certain tendencies can be identified. Analyzing the comparative results of different regions shown in Table 14, it appears that previous studies have a similar pattern in the distribution of impact in different activity categories. However discrepancies can be found: for example, the high emissions per trip to 
Mexico (555.2 kg eq CO $2 /$ visitor*day) (Grimm et al., 2008) in comparison to Barcelona results (103.1 kg eq $\mathrm{CO}_{2} /$ visitor*day). The reason for this is that the study for Mexico only includes the plane transport from Germany and that notably increases the resulting value. To calculate Barcelona results we have taken into account the average of total tourist or visitor trips to the city, regardless of the origin of the tourist and the mode of transport used. It is important to also specify that in Table 14, the comparative data used for Barcelona is only for tourists because the other studies do not consider the impact of day-trippers. On the other hand, Menorca (Sanyé-Mengual et al., 2014) obtained the lower value of daily tourist emissions because accommodation, Activities and intra-urban transport were not included in the study.

The study carried out in Iceland (Björnsson, 2014) is the only one that presents accommodation as the category with less impact, due to certain specifications of this case study. The main internal transports for tourists in Iceland are rental cars and the activities are mainly related to adventure activities, both are highly dependent on fuel combustion. Moreover, Iceland has extended forms of accommodation with lower energy intensity (particularly camping) and low accommodation energy consumption is also accentuated by the use of geothermal energy. Geothermal power facilities currently generate $25 \%$ of the Iceland total electricity production (Orkustofnun, 2015).

Additionally, the results were compared with the carbon footprint of the annual energy use for Barcelona city (including the domestic sector, commercial services, industry, transport and waste management), which is about 6 million tonnes of $\mathrm{CO}_{2}$ eq. The comparison of that figure with the 9.5 million tones generated by the tourist sector, underlines the importance of the tourist sector in environmental terms. According to the Energy balance of Barcelona 2013, from the Energy Climate Change and Air Quality Plan (PECQ) (Barcelona City Council \& Barcelona Energy Agency, 2013) the carbon footprint estimation for a Barcelona citizien is $5.8 \mathrm{~kg}$ $\mathrm{CO}_{2}$ eq /citizen•day on average.

Although the calculation method and the data do not allow a direct comparison, it shows that the daily carbon footprint for a visitor is one order of magnitude larger than the daily footprint of a resident. However, the visitors average includes both the activities in destination and the transportation to the touristic spot. When only the results in destination are analyzed, an overnight stay of a tourist in an upper category hotel (five stars) can exceed more than 8 times the daily emissions generated by a resident. Nonetheless, the tourism industry can take many steps towards becoming a green industry. 


\begin{tabular}{|c|c|c|c|c|c|c|c|c|c|c|c|c|}
\hline \multicolumn{13}{|c|}{ Comparative analysis } \\
\hline \multirow[b]{2}{*}{$\begin{array}{l}\text { Place of } \\
\text { the study }\end{array}$} & \multirow[b]{2}{*}{$\begin{array}{c}\text { Numbe } \\
\text { r of } \\
\text { nights/ } \\
\text { per trip }\end{array}$} & \multicolumn{5}{|c|}{ Carbon Footprint } & \multirow[b]{2}{*}{$\begin{array}{r}\text { Emissions per } \\
\text { stay }\end{array}$} & \multirow[b]{2}{*}{ Units } & \multirow[b]{2}{*}{$\begin{array}{r}\text { Emissions/ } \\
\text { tourist * } \\
\text { day }\end{array}$} & \multirow[b]{2}{*}{ Units } & \multirow[b]{2}{*}{ Observations } & \multirow[b]{2}{*}{ Source } \\
\hline & & $\begin{array}{r}\text { Travel to } \\
\text { and from } \\
\text { the } \\
\text { destination } \\
\end{array}$ & Accommodation & Food & $\begin{array}{r}\text { Urban/Internal } \\
\text { Transport }\end{array}$ & Activities & & & & & & \\
\hline Barcelona & 5.00 & $95.6 \%$ & $3.35 \%$ & - & $0.36 \%$ & $0.72 \%$ & 515.60 & $\mathrm{~kg} \mathrm{CO}_{2}$ eq & 103.12 & $\begin{array}{r}\mathrm{kg} \mathrm{CO}_{2} \text { eq } \\
\text { / tourist * day }\end{array}$ & Average & This study \\
\hline Mexico & 13.00 & $88.13 \%$ & $6.75 \%$ & $2.84 \%$ & - & $2.29 \%$ & $7,218.00$ & $\mathrm{~kg} \mathrm{CO}_{2}$ eq & 555.23 & $\begin{array}{r}\mathrm{kg} \mathrm{CO} \mathrm{CO}_{2} \text { eq } \\
\text { / tourist* day }\end{array}$ & $\begin{array}{l}\text { Calculation for } \\
\text { German tourists }\end{array}$ & (Grimm et al., 2008) \\
\hline Majorca & 13.00 & $75.70 \%$ & $12.11 \%$ & $7.45 \%$ & - & $4.75 \%$ & $1,222.00$ & $\mathrm{kgCO}_{2}$ eq & 94.00 & $\begin{array}{r}\mathrm{kg} \mathrm{CO}_{2} \text { eq } \\
\text { / tourist * day }\end{array}$ & $\begin{array}{l}\text { Calculation for } \\
\text { German tourist }\end{array}$ & (Grimm et al., 2008) \\
\hline Cyprus & 11.20 & $82.76 \%$ & $11.47 \%$ & - & $0.24 \%$ & $5.53 \%$ & 672.95 & $\mathrm{~kg} \mathrm{CO}_{2}$ & 66.00 & $\begin{array}{r}\mathrm{kg} \mathrm{CO}_{2} / \text { tourist } * \\
\text { day }\end{array}$ & $\begin{array}{r}\text { Calculation for } \\
\text { UK tourist } \\
\end{array}$ & (WWF - UK, 2002) \\
\hline Menorca & 20.00 & $77.83 \%$ & $6.21 \%$ & - & - & - & 277.00 & $\mathrm{~kg} \mathrm{CO}_{2}$ & 14.60 & $\begin{array}{r}\mathrm{kg} \mathrm{CO}_{2} / \text { tourist } * \\
\text { day }\end{array}$ & Average & $\begin{array}{r}\text { (Sanyé-Mengual et al., } \\
2014)\end{array}$ \\
\hline Antarctica & - & - & - & - & - & - & - & - & 490.00 & $\begin{array}{r}\mathrm{kg} \mathrm{CO}_{2} / \text { tourist } * \\
\text { day }\end{array}$ & Average & (Farreny et al., 2011) \\
\hline Iceland & 9.00 & $66.73 \%$ & $0.19 \%$ & - & $31.42 \%$ & $1.66 \%$ & 958.71 & $\mathrm{~kg} \mathrm{CO}_{2}$ & 106.52 & $\begin{array}{r}\mathrm{kg} \mathrm{CO}_{2} / \text { tourist } * \\
\text { day }\end{array}$ & Average & (Björnsson, 2014) \\
\hline Algarve & 10.00 & $83.90 \%$ & $13.40 \%$ & - & - & $2.70 \%$ & 627.5 & $\mathrm{~kg} \mathrm{CO}_{2}$ & 62.75 & $\begin{array}{r}\mathrm{kg} \mathrm{CO}_{2} / \text { tourist } * \\
\text { day }\end{array}$ & Trip is from UK & $\begin{array}{r}\text { (Filimonau, Dickinson, } \\
\text { Robbins, \& Vijay, 2013) }\end{array}$ \\
\hline Switzerland & - & $80.00 \%$ & $10.00 \%$ & $2.00 \%$ & $7.00 \%$ & $0.32 \%$ & 310.26 & $\mathrm{~kg}$ eq $\mathrm{CO}_{2}$ & - & - & Average & $\begin{array}{r}\text { (Perch-Nielsen, Sesartic, } \\
\& \text { Stucki, 2010) }\end{array}$ \\
\hline
\end{tabular}

Table 14. Comparative results of different studies of the impact of tourist emissions around the world. 


\section{Mitigation strategies}

The results obtained in this study identify the main sources of GHG emissions and can be used as a guide to propose strategies that reduce the carbon footprint of Barcelona related with the tourist activity. Regarding the results, the mitigation efforts have to focus on arrival and departure transport. Aviation is responsible for $89 \%$ of the carbon footprint of tourism in Barcelona. Notwithstanding the difficulties and lack of competences of local administration for dealing with the operations of the aeronautical sector, major efforts are needed to be made in this area.

Nowadays all types of aircraft used in civil aviation operate entirely on kerosene. One ton of kerosene produces 3.1 tons of $\mathrm{CO}_{2}$ as well as water vapor and nitrogen oxide. The aviation industry is responsible for 2-3\% of global GHG emissions from human activity (Cames, Graichen, Siemons, \& Cook, 2015). Some airline companies have developed corporate environmental strategies with the purpose of reducing their environmental impact; for example, improving in aircraft technology, collaborating in social and environmental projects and compensating emissions are the most common strategies.

Regarding Barcelona Airport, currently only 6 out of the 15 main airlines with flights from Barcelona Airport offer their customers the possibility to offsetting their flight emissions. The two main airline companies operating in Barcelona, with more than 50\% of passengers, do not offer the possibility to compensate the emissions generated. Despite the low offer, if $20 \%$ of passengers flying on airlines that offer the compensation chose this option 736,701 tonnes of $\mathrm{CO}_{2}$ eq could be offsetted annually.

Local administration could study the viability to apply a discount in tourist taxes for those visitors that can prove having offsetted their transport emissions. Apart from these voluntary measures, where the consumer is in effect paying for the compensation of the $\mathrm{CO}_{2}$ emissions, the airlines could actually internalize the environmental costs of the damage produced. Bieger and Wittmer (2006), underline the good practices of some airlines to get involved in the planning and development of tourist destinations, e.g., in advertising initiatives and the planning of airport access facilities.(Bieger \& Wittmer, 2006)

Another area of interest is the introduction of alternative aviation fuels generated from renewable resources, especially biomass. Technology is envisaged to play an increasingly important role in the mitigation of the carbon footprint attributed to tourism- and leisure-related travel. Within various technological solutions, biofuel is often considered a viable tool to tackle this issue (Pinheiro, Mattos \& Filimonau, 2017). A number of industrial commitments and collaborations have emerged to find alternative ways to develop efficient aviation biofuels (Nair \& Paulose, 2014). The production of alternative aviation fuels from renewable bioresources is a promising technology which is expected to substitute the petroleum based fuels (Kandaramath Hari, Yaakob \& Binitha, 2015).

A study about transport carbon footprint of Brazilian tourism shows the important finding signifying the crucial role of biofuel technology in reducing the carbon intensity because biofuel driven flights are found to generate less GHG emissions than cars powered by the conventional fuel (Pinheiro, Mattos \& Filimonau, 2017). The increasing interest of government and international organizations can help the scaling up, commercialization and supply chain infrastructure to a large extent. Over the past few years, some airlines, in collaboration with the aeronautical industry, have carried out test flights mixing kerosene with second generation biofuels. The results of the flight tests have been positive, showing reductions around $20 \%$ of GHG emissions. The use of mixed fuel can achieve savings of around 196 
tonnes of $\mathrm{CO}_{2}$ eq on a one way flight of $500 \mathrm{~km}$. A recent study led by NASA indicates that by using biofuels jet engines reduce particle emissions in their exhaust by 50 to $70 \%$ (Harrington, Barnstorff \& Dambowsky, 2017). In August 2017 the first commercial flight using the world's first renewable, alternative jet fuel made from the remains of logging and thinning from sustainably managed forests took off successfully (Washington Forest Protection Association, 2017).

On the other hand, the local agency for tourism promotion could focus on the promotion of proximity tourism making short-haul travel more attractive to people who currently prefer long-haul travel, as this is key to reducing airplane mileage and make transport by train or bus attractive for tourists and daytrippers.

Finally, regarding transportation from the airport to the city, local administration could promote a shift from car transport to other collective modes of transport, such as metro, train or bus. In addition, efforts from the local administration to electrify or hybridize the taxi fleet would also have a positive impact on the reduction of emissions.

Regarding GHG emissions in destination, accommodation is responsible for $75.6 \%$ of them. Therefore, the collaboration with accommodation providers is absolutely necessary. There is room for improvement in the entire accommodation sector, especially in the highest hotel categories. The promotion of carbon footprint metrics in the tourist accommodations and its subsequent monitoring may be helpful to these establishments to define objectives of reduction. As demonstrated through various sources and researches, when a hotel increases its level of environmental commitment it has a competitive advantage. A study about sustainable practices in Greek eco-friendly hotels (Kapiki, 2012), highlights some best practices to improve the traveler experience and the hotel consumption performance: the application of a green certification program; training and motivation of employees and the integration of the eco-label in the hotel marketing. Is important is to engage the tourist in the environmental best practices thus enhancing tourist's value perception about the eco-travel activity (HelenaChiu, Lee \& Chen, 2014). This is the first in a sequence of steps that would strengthen environmentally responsible behavior via increasing the ecotourist's activity involvement and satisfaction levels. In addition, local authorities could promote and provide support to the tourist accommodations in order to help them to obtain eco-label certifications, transit toward $100 \%$ renewable electricity supply, and to implement energy saving and efficiency measures.

\section{Conclusions}

This study calculates the carbon footprint of tourism in Barcelona as 9.5 million tonnes $\mathrm{CO}_{2} \mathrm{eq}$ originating directly or indirectly from the activity of 33 million visitors that the city received in 2015 . These figures represent an average carbon footprint per visitor of $96.9 \mathrm{~kg} \mathrm{CO}$ eq/day. This study divides visitors into two categories (tourists - stay overnight - and day-trippers) and for the first time they are analyzed separately.

The average carbon footprint of a tourist is $111.6 \mathrm{~kg} \mathrm{CO}_{2}$ eq /day and $43.0 \mathrm{~kg} \mathrm{CO}$ eq /day for a daytripper.

Regarding the sources of GHG emissions, arrival and departure transport has the highest contribution (95.9\% of total GHG emissions and $92.9 \mathrm{~kg} \mathrm{CO} 2 \mathrm{eq} /$ visitor•day). Accommodation, leisure and 
professional activities and intra-urban transport are responsible for only $4 \%$ of the carbon footprint of Barcelona visitors.

This large impact of transport is in line with results obtained by previous studies. However, it should be highlighted that Barcelona is a city that attracts a large volume of international tourists that commonly make short stays in the city (2-3 days). This profile maximizes the impact of arrival and departure transport, thus gaining more weight.

This study has involved great efforts in data collection, using quality sources and carrying out specific surveys to obtain data from tourist attractions and tourist accommodations. One important source that has been used is the Annual Survey that Barcelona City Council carries out to tourists visiting Barcelona. It has been detected that some information obtained from this survey could be more specific adding new questions or improving the existing survey questionnaire. The introduction of these changes could improve the calculations of the carbon footprint, obtaining more accurate results in categories such as waste, restaurants and the retail sector.

Despite being the main contributor to the environmental impact of tourism (Gössling, 2013), according to the Kyoto Protocol, emissions from international aviation should not be considered as part of national emissions. And until now, there is not a way to attribute aviation emissions to individual economies (Sharp, Grundius, \& Heinonen, 2016). Therefore, even in countries committed to reducing emissions, national mitigation plans do not include measures to reduce these emissions. In this context, and given its relevance, it is especially important that countries, municipalities and airlines reach agreements for accelerating the carbon compensation or the implementation of efficient technologies in the aviation sector.

It is also important to influence tourist habits by supplying data and information. Small changes, such as travelling to nearby destinations or increasing the use of collective modes of transport, can have a positive and real effect on the carbon footprint of tourism.

Finally, if tourist destinations had access to studies on their carbon footprint, this information could be used for managing and promoting the tourist offer; i.e. helping destinations to focus their tourism policies towards increasing sustainability and to prioritize their efforts to reduce not only local but also global impact.

\section{References}

Accor hotels (2011). The Accor group's Environmental Footprint. Retrieved from Accor Group webside: http://www.accorhotels.group/-/media/Corporate/Commitment/PDF-forpages/Planet21Research/Empreinte/Empreinte-

2011/2011_12_08_accor_empreinte_environnementale_dp_bd_en.pdf

Aena (2017). Estadísticas - Aeropuertos Españoles. Retrieved from: http://www.aena.es/csee/Satellite?pagename=Estadisticas\%2FHome

Andreea, L., Marian, A. \& Dimitriu, M. (2013). Carbon Footprint Analysis: Towards a Projects Evaluation Model for Promoting Sustainable Development. Procedia Economics and Finance, 
6(13), 353-363. http://doi.org/10.1016/S2212-5671(13)00149-4

Barcelona City Council \& Barcelona Energy Agency (2013). Energy balance of Barcelona 2013.

Barcelona, Spain. Retrieved from:

http://ajuntament.barcelona.cat/ecologiaurbana/sites/default/files/Balanc-energia-

Barcelona_2013.pdf

Barcelona City Council (2015). Barcelona Tourism Activity Report. Barcelona, Spain.

Barcelona City Council (2016a). Tourist Activity in the City of Barcelona 2015. Survey results. Barcelona, Spain.

Barcelona City Council (2016b). Touristic Mobility Plan of Barcelona. Chapter 3. Characterization of touristic mobility (Demand). Working document, September 2016. Barcelona, Spain.

Barcelona City Council (2016c). Touristic Mobility Plan of Barcelona. Chapter 4. Touristic mobility assessment. Working document, September 2016. Barcelona, Spain.

Barcelona City Council. (2016d). Report of the tourist activity in Barcelona 2015. Barcelona Tourism. Barcelona, Spain.

Barcelona City Council. (2017) Annual statistics of Barcelona city 2015. Retrieved from: http://www.bcn.cat/estadistica/castella/dades/anuari/cap13/index.htm

Barcelona Provincial Council. (2016). Characterization of Tourists in the Province of Barcelona 2015. Barcelona city council, Barcelona Provincial Council and Barcelona Tourism. Survey Presentation. DYM. Barcelona, Spain.

Barcelona Tourism, Barcelona City Council \& Barcelona Provincial Council. (2016). Tourism statistics 2015, Barcelona: city and surroundings. Retrieved from http://professional.barcelonaturisme.com/imgfiles/estad/Est2015.pdf

Becken, S., Frampton, C. \& Simmons, D. (2001). Energy consumption patterns in the accommodation sector - the New Zealand case. Ecological Economics, 39, 371-386. http://doi.org/10.1016/S09218009(01)00229-4

Becken, S. \& Simmons, D. G. (2002). Understanding energy consumption patterns of tourist attractions and activities in New Zealand. Tourism Management, 23(4), 343-354. http://doi.org/10.1016/S0261-5177(01)00091-7

Bieger, T. \& Wittmer, A. (2006). Air transport and tourism - Perspectives and challenges for destinations, airlines and governments. Journal of Air Transport Management, 12(1), 40-46. http://doi.org/10.1016/j.jairtraman.2005.09.007

Björnsson, V. J. (2014). Estimated carbon footprint of foreign tourists in iceland - a bottom-up analysis of direct CO2 emissions. School of Engineering and Natural Sciences, Master.

Cames, M., Graichen, J., Siemons, A. \& Cook, V. (2015). Emission Reduction Targets for International Aviation and Shipping. Study for the ENVI Committee. European Union (Vol. 53).

Díaz Pérez, F.J., Chinarro, D., Guardiola Mouhaffel, A. et al. (2018). Comparative study of carbon footprint of energy and water in hotels of Canary Islands regarding mainland Spain. Environment, Development and Sustainability, pp 1-18. https://doi.org/10.1007/s10668-018-0102-6

Dolnicar, S., Laesser, C. \& Matus, K. (2010). Short-haul city travel is truly environmentally sustainable. Tourism Management, 31(4), 505-512. http://doi.org/10.1016/j.tourman.2009.06.002 
Duatis,J., Buhigas, M. \& Cruz, H.(2016). Impact of Vacation Rentals in the Residential Rent Market of Barcelona. Retrieved from Barcelona City Council Website: https://ajuntament.barcelona.cat/turisme/sites/default/files/160921_informe_impacte_lloguer_vacac ional.pdf

Dwyer, L., Forsyth, P., Spurr, R. \& Hoque, S. (2010). Estimating the carbon footprint of Australian tourism. Journal of Sustainable Tourism, 18(3), 355-376. http://doi.org/10.1080/09669580903513061

European Cities Marketing (ECM). (2017). Tourism in European Cities continued to grow by $3.6 \%$ in 2016. Retrieved from: https://www.europeancitiesmarketing.com/tourism-european-citiescontinued-grow-3-6-2016/

Farreny, R., Oliver-Solà, J., Escuder-Bonilla, S., Roca-Martí, M., Sevigné, E., Gabarrell, X. \& Rieradevall, J. (2012). The metabolism of cultural services. Energy and water flows in museums. Energy and Buildings, 47, 98-106. http://doi.org/10.1016/j.enbuild.2011.11.050

Farreny, R., Oliver-Sola, J., Laers, M., Amelung, B., Gabarrell, X., Rieradevall, J., ... Benayas, J. (2011). Carbon Dioxide Emissions of Antarctic Tourism. Antarctic Science, 23(6), 556-566. http://doi.org/10.1017/S0954102011000435

Filimonau, V., Dickinson, J. \& Robbins, D. (2014). The carbon impact of short-haul tourism: A case study of UK travel to Southern France using life cycle analysis. Journal of Cleaner Production, 64, 628-638. http://doi.org/10.1016/j.jclepro.2013.07.052

Filimonau, V., Dickinson, J., Robbins, D. \& Vijay, M. (2013). The role of “ indirect” greenhouse gas emissions in tourism: Assessing the hidden carbon impacts from a holiday package tour. Transportation Research Part A, 54, 78-91. http://doi.org/10.1016/j.tra.2013.07.002

Garriga, A., \& Rigall, R. (2015). L’impacte econòmic de l'activitat turística a la ciutat de Barcelona. (Unpublished master's thesis). Girona University, Grirona, Spain.

Gössling, S. (2002). Global environmental consequences of tourism. Global Environmental Change, 12(4), 283-302. http://doi.org/10.1016/S0959-3780(02)00044-4

Gössling, S. (2013). National emissions from tourism: An overlooked policy challenge? Energy Policy, 59, 433-442. http://doi.org/10.1016/j.enpol.2013.03.058

Grassl, H. \& Brockhagen, D. (2007). Climate Forcing of Aviation Emissions in High Altitudes and Comparison of Metrics: An Update According to the Fourth Assessment Report, IPCC, Hamburg: Max Planck Institute of Meteorology. December, available at https://www.mpimet.mpg.de/fileadmin/download/Grassl_Brockhagen.pdf

Grimm, B., Beer, H., Günther, W., \& Weerts, B. (2008). The Tourist Climate Footprint WWF Report on environmental impacts of holiday trips. Retrieved from: http://81.47.175.201/stodomingo/attachments/article/12/tourists_climate_footprint.pdf

Harrington, J. D., Barnstorff, K., \& Dambowsky, F. (2017). Biofuels Reduce Jet Engine Pollution. Retrieved from https://www.nasa.gov/press-release/nasa-study-confirms-biofuels-reduce-jetengine-pollution

Hartmann, D. L., Tank, a. MGK., \& Rusticucci, M. (2013). IPCC Fifth Assessment Report, Climate Change 2013: The Physical Science Basis. Ipcc, AR5(January 2014), $31 \quad$ - 39. 
http://doi.org/10.1017/CBO9781107415324

Hedrick-Wong, Y. \& Choog, D. (2016). Global Destination Cities Index. Retrieved from http://newsroom.mastercard.com/wp-content/uploads/2013/05/Updated-

Mastercard_GDCI_Final_V4.pdf

HelenaChiu Y., Lee W. \& Chen T. (2014). Environmentally responsible behavior in ecotourism: Antecedents and implications. Tourism Management, Volume 40, pp 321-329. https://doi.org/10.1016/j.tourman.2013.06.013

IERMB. (2007b). Survey of Daily Mobility of Catalonia 2006. 1. Daily Mobility. Institute of Barcelona Regional and Metropolitan Studies. Department of Public Works and the Metropolitan Transportation Authority (MTA).

IERMB. (2007a). Survey of Daily Mobility of Catalonia 2006. Firsts results. Institute of Barcelona Regional and Metropolitan Studies. Department of Public Works and the Metropolitan Transportation Authority (MTA).

IPK International \& ITB Academy. (2017). ITB World Travel Trends Report 2016/2017.

Kandaramath Hari, T., Yaakob, Z., \& Binitha, N. N. (2015). Aviation biofuel from renewable resources: Routes, opportunities and challenges. Renewable and Sustainable Energy Reviews. http://doi.org/10.1016/j.rser.2014.10.095

Kapiki, S. (2012). Implementing Sustainable Practices in Greek Eco-Friendly Hotels. Journal of Environmental Protection and Ecology, Vol. 13, No, 2A, pp. 1117-1123, 2012

Kreag, G. (2001). The Impacts of Tourism. Minnesota Sea Grant, (T 13), 1-20. Retrieved from www.seagrant.umn.edu

Lee, D. S., Lee, D. S., Pitari, G., Pitari, G., Grewe, V., Grewe, V., ... Sausen, R. (2009). Transport impacts on atmosphere and climate: Aviation. Atmospheric Environment, 44(37), 1-57. http://doi.org/10.1016/j.atmosenv.2009.06.005

Lenzen, M., Sun, Y., Faturay, F., Ting, Y., Geschke, A. \& Malik, A. (2018). The carbon footprint of global tourism. Journal of Nature Climate Change, volume 8, pages522-528. https://doi.org/10.1038/s41558-018-0141-x

Maćkiewicz B., Konecka-Szydłowska B. (2017) Green Tourism: Attractions and Initiatives of Polish Cittaslow Cities. In: Bellini N., Pasquinelli C. (eds) Tourism in the City, pp 297-309. Springer, Cham. https://doi.org/10.1007/978-3-319-26877-4_21

Michailidou, A. V., Vlachokostas, C., Moussiopoulos, N., \& Maleka, D. (2015). Life Cycle Thinking To Assess The Environmental Impacts Of Tourism Activity for a Greek Tourism Destination. Journal of Cleaner Production, 111, 499-510. http://doi.org/10.1016/j.jclepro.2015.09.099

Nair, S., \& Paulose, H. (2014). Emergence of green business models: The case of algae biofuel for aviation. Energy Policy, 65, 175-184. http://doi.org/10.1016/j.enpol.2013.10.034

Orkustofnun. National Energy Authority. (2015). Geothermal. Retrieved from http://www.nea.is/geothermal/

Peeters, P., \& Schouten, F. (2006). Reducing the ecological footprint of inbound tourism and transport to Amsterdam. Journal of Sustainable Tourism, 14(2), 157-171. http://doi.org/10.1080/09669580508669050 
Perch-Nielsen, S., Sesartic, A. \& Stucki, M. (2010). The greenhouse gas intensity of the tourism sector: The case of Switzerland. Environmental Science and Policy, 13(2), 131-140. http://doi.org/10.1016/j.envsci.2009.12.002

Pinheiro R., Mattos G. \& Filimonau V. (2017). The carbon footprint appraisal of local visitor travel in Brazil: A case of the Rio de Janeiro-São Paulo itinerary. Journal of Cleaner Production, volume 141, pp 256-266. https://doi.org/10.1016/j.jclepro.2016.09.049

Port of Barcelona \& Barcelona city council. (2015a). Report of results: Barcelona cruise passengers in 2014. Survey results. Presentation. DYM.

Port of Barcelona \& Barcelona Tourism. (2015b). Cruise activity in Barcelona. Impact on the Catalan economy socioeconomic profile of the cruiser 2014. Retrieved from http://professional.barcelonaturisme.com/imgfiles/estad/Informe_ACPBCN_2014_CAST_web.pdf

$\mathrm{Pu}$ W. \& Mi T. (2016). On Estimating Transportation Energy Consumption and Carbon Dioxide Emissions from Off-Shore Island Tourism-A Case Study of Haikou City, China. Journal of Resources and Ecology 20167 (6), 472-479. https://doi.org/10.5814/j.issn.1674-764x.2016.06.007

Puig R., Kiliç E., Navarro A., Albertí J., Chacón L. \& Fullana-i-Palmer P., (2017). Inventory analysis and carbon footprint of coastland-hotel services: A Spanish case study. Science of The Total Environment. Volume 595 (2017), Pages 244-254. https://doi.org/10.1016/j.scitotenv.2017.03.245

Sanyé-Mengual, E., Romanos, H., Molina, C., Oliver, M. A., Ruiz, N., Pérez, M., Carreras, D., Boada, M., Garcia-Orellana, J., Duch, J., Rieradevall, J. (2014). Environmental and self-sufficiency assessment of the energy metabolism of tourist hubs on Mediterranean Islands: The case of menorca (Spain). Energy Policy, 65, 377-387. http://doi.org/10.1016/j.enpol.2013.10.011

Sharp H., Grundius, J. \& Heinonen, J. (2016). Carbon Footprint of Inbound Tourism to Iceland: A Consumption-Based Life-Cycle Assessment including Direct and Indirect Emissions. Sustainability, 8(11), 1147. http://doi.org/10.3390/su8111147

Simmons C. \& Lewis K., 2001. Take only memories...leave nothing but footprints: An ecological footprint analysis of two package holidays. Rough Draft Report. Best Foot Forward Limited, Oxford.

Sisman D., \& Associates (2007). Retrieved from: http://www.clima net.org/docs/elibrary/ekthesis/tourismdestinations\%20.pdfhttp://www.climanet.org/docs/elibrary/ekthesis/tourismdestinations\%20.pdf

Tourism Directorate. (2017). Working domcument. Energy consumption of Barcelona tourist accommodation.

Catalonia Tourism Law, 13/2002, 3669 DOGCN (CAT).

UNWTO. (2012). Global Report on City Tourism AM Reports: Volume six. Retrieved from http://dtxtq4w60xqpw.cloudfront.net/sites/all/files/pdf/am6_city_platma.pdf

UNWTO. (2015). UNWTO Annual Report 2014. World Tourism organization. Retrieved from http://cf.cdn.unwto.org/sites/all/files/pdf/unwto_annual_report_2014.pdf

Washington Forest Protection Association. (2017). Biofuel from forests lightens jetliner carbon footprint. Retrieved from http://www.seattletimes.com/sponsored/biofuel-from-forests-lightens-jetlinercarbon-footprint/ 
Wiedmann, T. \& Minx, J. (2008). A Definition of' Carbon Footprint. C. C. Pertsova, Ecological Economics Research Trends, 1(January 2008), 1-11. , Nova Science Publishers, Hauppauge NY, USA. Retrieved from https://www.novapublishers.com/catalog/product_info.php?products_id=5999.

WTO, WMO, \& UNEP. (2008). Responding to Global Challenges Climate Change and Tourism Responding to Global Challenges. Change. http://doi.org/10.1007/978-3-7908-1718-8

WWF - UK. (2002). Holiday Footprinting. A Practical Tool for Responsible Tourism.

Zorpas A.A., Voukkali I. \& Navarro J. (2017). Tourist area metabolism and its potential to change through a proposed strategic plan in the framework of sustainable development. Journal of Cleaner Production, 172 (2018), 3609 - 3620. https://doi.org/10.1016/j.jclepro.2017.02.119 